\title{
Dismantling the treasured flagship lichen Sticta fuliginosa (Peltigerales) into four species in Western Europe
}

\author{
Nicolas Magain $^{1,2} \cdot$ Emmanuël Sérusiaux ${ }^{1}$
}

Received: 6 May 2015 /Revised: 23 August 2015 / Accepted: 25 August 2015

(C) German Mycological Society and Springer-Verlag Berlin Heidelberg 2015

\begin{abstract}
In the framework of a worldwide project on the phylogeny of the lichen genus Sticta, dedicated sampling was performed in four regions of Western Europe, roughly along an east-west line between $\mathrm{N} 48^{\circ} 02^{\prime} \mathrm{E} 07^{\circ} 01^{\prime}$ and $\mathrm{N}$ $52^{\circ} 01^{\prime} \mathrm{W} 09^{\circ} 30^{\prime}$, ranging from France/Vosges to Ireland/ Kerry. Five clearly distinct ITS haplotypes were detected for isidia-producing species where only two were expected. Subtle anatomical and morphological characters, together with a strongly supported 4-loci molecular phylogeny, permit distinguishing, besides the easily recognized $S$. canariensis and S. limbata: 1) the two well-known S. fuliginosa and S. sylvatica, whose type collections have been carefully reassessed; the former is widespread in both hemispheres, while the latter is correctly identified only from continental Europe and the Andes in Colombia. The barcode ITS of S. fuliginosa differs by a single substitution from $S$. limbata (with a single exception), and the 4-loci phylogenetic tree does not resolve them as distinct lineages, most probably highlighting a very recent divergence and incomplete lineage sorting. 2) Three species that were formely included in S. fuliginosa: the resurrected $S$. ciliata Taylor, belonging to a complex group yet to be disentangled and occurring in the Neotropics, Africa, Macaronesia, and Western Europe, and two species described as new to science, S. fuliginoides, found in continental Europe, the Canary Islands, eastern North America, and
\end{abstract}

Section Editor: Franz Oberwinkler

Emmanuël Sérusiaux

E.Serusiaux@ulg.ac.be

1 Evolution and Conservation Biology, University of Liège, Sart Tilman B22, B-4000 Liège, Belgium

2 Present address: Department of Biology, Duke University, Durham, NC 27708, USA
Colombia, and S. atlantica only known from Ireland and the Azores archipelago. Molecular inferences demonstrate active divergence and dispersion within $S$. ciliata that may require recognition of further species. Fresh material can be identified with a morphological and anatomical preliminary key provided here. We propose that the taxonomy of all lichen species be urgently reviewed in the light of molecular data in an evolutionary context, particularly those used as bioindicators of environmental change and woodland management.

Keywords Lichenized fungi $\cdot$ Peltigerales $\cdot$ Phylogeny Taxonomy

\section{Introduction}

The lichen genus Sticta features as one of the best-known macrolichens, easily recognized by its most usually large thalli, well-differentiated small pores on the lower surface (named cyphellae) and a typical fishy smell in wet conditions because of methylamines production. It is subcosmopolitan, being well-developed and diverse in humid, cool- to warmtemperate environments. It is thus most conspicuous, together with other genera in the Peltigerales such as Lobaria, Peltigera, and Pseudocyphellaria, and representatives of the families Collemataceae and Pannariaceae, in temperate humid coastal areas (northwestern coast of North America, southern Chili, Tasmania, and New Zealand) and in tropical montane forests, with an impressive diversity in the northern Andes in Colombia (Moncada and Lücking 2012; Moncada et al. 2013b, c, 2014a, b; Suárez and Lücking 2013). It occurs at low elevation as well, including in tropical areas, with less diversity and biomass, and is completely absent in desert habitats and dry forests. 
The genus Sticta belongs to the Lobariaceae, which now includes 13 genera (Moncada et al. 2013a; Miadlikowska et al. 2014a; Galloway 2015). Pending that species in the S. wrightii gr. (incl. S. nylanderiana, S. praetextata, $S$. oroborealis, and $S$. wrightii) are referred to an autonomous genus (Dendriscosticta), the genus is strongly supported by phylogenetic analyses with inferences from molecular data (Högnabba et al. 2009; Miadlikowska et al. 2014a; Moncada et al. 2014a). As in several other lineages in the Peltigerales, it can establish a symbiotic association with either cyanobacteria (belonging to the genus Nostoc) or green algae (belonging to the genus Dictyochloropsis), or both. A rather simple photomorph pattern occurs in several clades within Sticta s. str.: it is made of two different foliose thalli, fixed one to the other or not; the one associated with Nostoc most usually has a typically strongly maculate upper cortex (Magain et al. 2012a; Moncada et al. 2013b). Dedicated structures including Nostoc colonies (named cephalodia) on the surface of or inside a green thallus do not occur in the genus. Dendriscocaulon-like cyanomorphs such as those of the Lobaria amplissima group (Ricasolia) are now referred to Dendriscosticta or to stipitate species of Sticta (Galloway 2001, 2007; Magain et al. 2012a). Indeed, Dendriscocaulon dendriothamnodes and $D$. dendroides are either free-living or associated with stipitate species of Sticta, S. stipitata, and S. filix respectively, and it is likely that all the caulescent species of Sticta will have Dendriscocaulon states (Galloway 2007).

Prior to the studies of Moncada and Lücking (2012), Moncada et al. (2013b, c, 2014a, b) and Suárez and Lücking (2013), the genus contained 114 accepted species, with only a few recently described (Aptroot 2008; Øvstedal and Gremmen 2010; Upreti and Divakar 2010; Lumbsch et al. 2011), and a single study focussed on species delimitation with molecular data combined with morphological and anatomical characters (McDonald et al. 2003). The revision of large collections recently gathered in Colombia, especially in the paramos vegetation belt, together with our own data assembled from Macaronesia, continental Africa, as well as Madagascar and the Mascarene archipelago, highlights a very different picture: the easily recognized morphotypes (all lichenized with Nostoc), such as that of $S$. fuliginosa (hardly branched thallus with rounded lobes and laminal isidia), $S$. weigelii (branched thallus with narrow lobes and marginal isidia), S. sylvatica (branched thallus with narrow lobes and laminal isidia), or S. sublimbata (branched thallus with narrow lobes and marginal isidioid soralia), are resolved into several mostly unrelated lineages (Moncada et al. 2014a). Many further species can thus be distinguished on a sound phylogenetical basis.

In Europe, the genus is considered a straightforward genus with four well-known species (Lambinon 1969; Llimona and Hladun 2001; Burgaz and Martínez 2003; Jørgensen and Tønsberg 2007; Smith et al. 2009; Wirth et al. 2013): $S$. canariensis (Flörke) Delise, with its green photomorph unique in the European context and its cyanomorph with a maculate upper surface and a crisped margin with phyllidia (also known as S. dufourii Delise), S. limbata (Sm.) Ach. with marginal soralia, and the duo S. fuliginosa (Hoffm.) AchS. sylvatica (Huds.) Ach., both with laminal isidia and being mainly distinguished by their branching pattern. Actually, the taxonomy of Sticta species in Europe has not changed since 1826 when the magistral work of Delise provided detailed descriptions for many species around the world, including S. canariensis, S. dufourii, S. fuliginosa, S. limbata, and S. sylvatica (Delise 1826). Quite obviously, Delise did not recognize that Sticta canariensis was the green photomorph of $S$. dufourii, first demonstrated by Armaleo and Clerc (1991), as he could not even imagine the dual nature of a lichen thallus that was eventually discovered decades later by Schwendener (1868).

In Europe, all species in the Lobariaceae, especially Sticta, enjoy a special status as they are recognized as patrimonial in most countries, and greatly suffer from air pollution and habitat disturbance. They indeed qualify for being very sensitive to human activities and are considered pertinent bioindicators and priority targets of conservation programs. Species of Sticta play a crucial role in the calculation of Indices of Ecological Continuity for woodland habitats in the British Isles (Coppins and Coppins 2002), as well as in the Pacific Northwest in North America (Tønsberg and Goward 2001; Doering and Coxson 2010; Radies and Coxson 2004; Radies et al. 2009). They also indicate very low levels of nitrogen deposit in forests throughout Europe (Giordani et al. 2014) and were recently included in newly designed indices for air quality in the Pacific Northwest (Root et al. 2015). However, the role of several ecological drivers (woodland extent and continuity, air pollution regime and climate) at regional scale and their interaction are complex, and no single and simple model can be designed to explain the composition and richness of epiphytic lichen vegetation, especially in the framework of climate change (Ellis 2012, 2013). Nevertheless, and especially at the margins of their distribution area, species of Sticta receive much attention, as demonstrated by the dedicated action plan proposed for Swedish species (Hultengren 2005).

However, there is no a priori reason to profess that the genus is less diverse in Europe than in other regions of the world, and that the Delise taxonomy, almost two centuries old, still is on the right track in the molecular age. We thus sampled the genus in four ecoregions in Western Europe, from the Vosges in France where the two most widespread species occur (S. fuliginosa and S. sylvatica), although they are quite rare in central Europe (Degelius 1935; Wirth et al. 2013), to SW Ireland where the four species are known to occur (Smith et al. 2009). The aim of this paper is to present the results of this work, together with a preliminary key for the identification of the European species of this emblematic and cherished, yet poorly known, genus. 


\section{Material and methods}

This work is mainly based on the comparison of molecular and morphological and anatomical data of fresh material. The localities were chosen as representative of the continental environment where the two most familiar species (reported as Sticta fuliginosa and S. sylvatica) occur and more oceanic environments where the four European species have been recorded (reported as S. canariensis, S. fuliginosa, S. limbata and $S$. sylvatica). The localities are the following:

- France, Dept. Haut-Rhin, Hohneck, N $48^{\circ} 02^{\prime}$ E $07^{\circ} 01^{\prime}$, c. $1000 \mathrm{~m}$ elev., sampled by the authors; this locality is representative of the Vosges ridge where species of Lobaria (L. amplissima, L. pulmonaria, and L. scrobiculata) and Sticta fuliginosa and S. sylvatica occur, as well as other species typical of Lobarion communities such as Nephroma parile, $N$. resupinatum, and Peltigera collina; similar localities occur in the Black Forest on the right side of the Rhine graben (Wirth 1995; Wirth et al. 2013);

- France, Dept. Finistère (part of Brittany), sampled by B. Bouffinier, A. Gérault and F. Séité at several localities well known for their interesting epiphytic flora (Coppins 1971; Aptroot et al. 2007; http://www.lichensmaritimes. org), incl. Huelgoat (N $48^{\circ} 22^{\prime} \mathrm{W} 03^{\circ} 44^{\prime}$, c. $150-200 \mathrm{~m}$ elev.), the Chaos de St-Herbot (N $48^{\circ} 20^{\prime}$ E $03^{\circ} 48^{\prime}$, c. 200-220 m) and the Cranou forest (N 48 $19^{\prime}$ E $04^{\circ} 05^{\prime \prime}$, c. 140-200 m elev.);

- United Kingdom/Somerset, Horner woods, N 51 $1^{\circ} 10^{\prime} \mathrm{W}$ $03^{\circ} 35^{\prime}$, c. $290 \mathrm{~m}$ elev., sampled by Pat Wolseley; Ibid./ Devon, Popham Woods, Brayford, N 51 ${ }^{\circ} 4^{\prime} 50^{\prime \prime}$ W $3^{\circ} 51^{\prime}$ $32^{\prime \prime}$, sampled by the authors; Ibid., Sampford Spiney, N $50^{\circ} 32^{\prime} 3^{\prime \prime}$, W $4^{\circ} 3^{\prime} 37^{\prime \prime}$, sampled by the authors; the SW part of England is renowned for its epiphytic lichen flora (Seaward 1998);

- Ireland/Kerry, Killarney, N $52^{\circ} 01^{\prime}$ W $09^{\circ} 30^{\prime}$, c. $30-40$ m elev. (centered on Muckross), a renowned protected area, whose lichen flora has been thoroughly explored (Giavarini 2012); sampling by the authors was made after a major thunderstorm that fell down hundred of trees (Feb. 2014), collecting has been restricted to fallen trees.

These localities are considered representative of continental Europe and referred to as continental Europe. Macaronesia refers to the three archipelagos of the Azores, Madeira, and the Canary Islands, and of course are not considered part of continental Europe.

As all species of Sticta are rare and vulnerable throughout most regions of Western Europe, collecting was prudent and parsimonious and concentrated on specimens growing on fallen trees or branches, or in unsustainable conditions such as "ready to fall" because of recent disturbance. Vouchers are preserved in the LG herbarium.

\section{Molecular data}

Extraction of DNA followed the protocol of Cubero et al. (1999). We sequenced the ribosomal nuclear loci ITS using primers ITS1F (Gardes and Bruns 1993) and ITS4 (White et al. 1990) for all collections assembled for this study (188 specimens). Little variation was detected for the barcode ITS, except for Sticta ciliata, which comprised several haplotypes in the material from continental Europe and Macaronesia. We thus selected a representative specimen of each species and haplotype detected in each of the four localities prospected for this study and produced LSU, mtSSU, and RPBI sequences for them. We added data obtained from our own collections from Madagascar, Reunion in the Mascarene archipelago, the Albertine Rift in East Africa (Congo RDC and Rwanda), and Macaronesia (the Azores and the Canary Is.). We further added data obtained from recently collected material by B.J. Coppins in Scotland, P. K. Divakar in the Azores archipelago, B. Goffinet in USA/North Carolina and South Africa, T. Goward in Canada/British Columbia, and P. van den Boom in the Canary Islands.

LSU primers were LR0R and either LR7 (Vilgalys and Hester 1990) or LIC2044 (Kauff and Lutzoni 2002), the mitochondrial ribosomal locus mtSSU primers were SSU1 and SSU3R (Zoller et al. 1999) and for part of the protein-coding gene RPB1, with RPB1AF (Stiller and Hall 1997) and RPB1CR (Matheny et al. 2002). Amplicons were sequenced by Macrogen $(\mathcal{C}$ or by the GIGA biotechnology platform of the University of Liège.

\section{Sequences editing and alignment}

Sequence fragments were assembled with Sequencher version 4.9 (Gene Codes Corporation, Ann Arbor, MI, USA). Sequences were subjected to megaBLAST searches (Wheeler et al. 2007) to detect potential contaminations. Sequences were aligned manually using MacClade version 4.08 (Maddison and Maddison 2005) and checked with the MAFFT software (Katoh and Standley 2013). Ambiguous regions were delimited with the GBLOCK server (Castresana 2000), using the default parameters and manually checked; all ambiguous regions were excluded from the analyses. The data matrix is deposited in TreeBASE under the accession \# 17996.

\section{Concatenation and partitioning}

Congruence of the four fungal loci was assessed by the comparison of single-locus phylogenetic trees produced with RAxML HPC2 version 7.2.8 (Stamatakis 2006; Stamatakis et al. 2008) as implemented on the CIPRES portal (Miller et al. 2010), looking 
for the best ML tree and bootstrapping with 1000 pseudoreplicates in the same run, using GTRCAT model and the default settings. No significant conflict with bootstrap values $\geq 70 \%$ was detected; therefore, the four loci were concatenated in a single data set. Two matrices were assembled, one containing 54 accessions of Sticta and one accession of Pseudocyphellaria crocata as outgroup, and a second one containing two additional ITS sequences of Sticta "microisidiata ad. int." from Colombia retrieved from GenBank. After removal of the ambiguous characters, the total length of each of these two matrices was 3090 characters. These matrices were partitioned in different subsets in order to optimize likelihood analyses. PartitionFinder (Lanfear et al. 2012) was chosen to determine the best partition and select the best models for the different subsets. We used the greedy algorithm and BIC as the criterion to define the best partition and compared all models available. The dataset tested for the analysis on the four loci was composed of eight subsets: $R P B 1,1$ st codon position; $R P B 1,2$ nd codon position; $R P B 1$ 3rd codon position; $R P B 1$ intron; $\mathrm{mtSSU}$; LSU; ITS1/ITS2 and 5.8S.

\section{Maximum likelihood and Bayesian phylogenetical analyses}

For both matrices, the best likelihood tree was produced with RAxML version 7.4.2 (Stamatakis 2006) with the default settings and the GTRCAT model and bootstrapped for 1000 pseudoreplicates in the same run, using the best partition obtained by PartitionFinder. We further ran for both matrices a Bayesian analysis using MrBayes version 3.2.3 (Huelsenbeck and Ronquist 2001) on the CIPRES portal (Miller et al. 2010) using the partition and the substitution models determined by PartitionFinder and running for 20,000,000 generations and sampling every 1000th generation. Each analysis consisted of two runs of three heated chains and one cold one. We assessed the convergence using Tracer version 1.5 (Rambaut and Drummond 2007) and checking with AWTY (Nylander et al. 2008) that convergence was reached for each run and that tree topologies have been sampled in proportion to their true posterior probability distribution. The first 2000 trees were discarded as burn-in. Branches of the phylogenetic trees produced are considered strongly supported if bootstrap support is higher than $70 \%$ for maximum likelihood analysis and posterior probabilities higher than 0.95 for the Bayesian analysis.

\section{Parsimony analysis for ITS data}

Thanks to data kindly made available to us by B. Moncada and R. Lücking, we could assemble an ITS matrix including all species, described or undescribed, from Colombia and assess their relationships with our own accessions. As the purpose of this analysis was to evaluate the position of the species dealt with in this study in the main clades identified by
Moncada et al. (2014a), we performed a maximum parsimony analysis with PAUP*4.0 (Swofford 2002). All ambiguous positions were strictly eliminated in the assembled matrix with the GBLOCKS server (Castresana 2000), using the default parameters and manually checked. An initial run was performed by using the tree bisection reconnection (TBR) branch swapping algorithm, with the steepest descent turned on and only 10 trees saved for each of the 200 random addition replicates; a second analysis was performed where all saved trees were swapped to completion with no limit to the number of trees saved.

\section{Haplotypes networks}

To analyse the genealogical relationships among the haplotypes, we constructed haplotype networks for two species (S. ciliata and S. fuliginoides sp. nov.) and for two closely related ones ( $S$. fuliginosa and $S$. limbata). The haplotype networks were calculated using the program TCS version 1.21 (Clement et al. 2000), which implements the statistical parsimony estimation as described by Templeton et al. (1992). The connection limit of the networks was fixed to $90 \%$ of the positions and gaps were treated as fifth character state.

\section{Morphological, anatomical, and chemical characters}

Morphological description as well as anatomical characters examined follow Tables 2 and 3 provided by Moncada et al. (2014a). Special attention was dedicated to the characters highlighted by Moncada and Lücking (2012) and especially the branching type, the two types of tomentum, and the membrane of cyphellae. Indeed, the presence of papillae on the cells of the surface of the cyphellae membrane was found to discriminate $S$. fuliginosa s. str. from two other species (S. ciliata and $S$. fuliginoides sp. nov.) that were so far engulfed in it. TLC analysis of two specimens of each species dealt with in this paper has been performed following the protocol of solvent $\mathrm{C}$ and visualization of spots with a $10 \%$ sulphuric acid solution (Orange et al. 2010).

\section{Results}

\section{Molecular data and phylogenetic analyses}

We amplified ITS for 188 specimens (45 included in the 4-loci analysis: see below), and a further 43 for nuLSU, 44 for $\mathrm{mtSSU}$, and 49 for RPB1 (Table 1). PartitionFinder divided the partition into six subsets: one composed of LSU (best model: $\operatorname{Tr} \mathrm{N}+\mathrm{I}+\mathrm{G})$, one with $\mathrm{mtSSU}(\mathrm{HKY}+\mathrm{I})$, one with ITS1 and ITS2 $(\mathrm{TIM}+\mathrm{G})$, one with 5.8S and RPB1 2nd codon position $(\mathrm{JC}+\mathrm{I})$, one with $R P B 1$ 1st codon position $(\mathrm{TrN}+\mathrm{I})$, and one with $R P B 1$ 3rd codon position and $R P B 1$ intron ( $\operatorname{TrNef}+\mathrm{I}+\mathrm{G})$. 
Table 1 Specimens and DNA sequences used in this study, with their respective voucher information

\begin{tabular}{|c|c|c|c|c|c|c|}
\hline & Epithet (Sticta) & Voucher & ITS & $\mathrm{mtSSU}$ & nuLSU & $R P B 1$ \\
\hline 1 & ambavillaria & France, Réunion, 2009, N. Magain \& E. Sérusiaux (LG 992) & JQ735978 & JQ736011 & JQ735995 & - \\
\hline 2 & atlantica & Ireland, Kerry, 2014, E. Sérusiaux (LG 3747) & KT281734 & KT281690 & KT281645 & - \\
\hline 3 & atlantica & Portugal, Azores, Pico, 2014, E. Sérusiaux (LG 3858) Type & KT281737 & KT281693 & KT281648 & KT281784 \\
\hline 4 & beauvoisii & USA, North Carolina, 2013, B. Goffinet 11137 (LG 3303) & KT281725 & KT281681 & KT281636 & KT281787 \\
\hline 5 & canariensis & Spain, Canary Is., Tenerife, 2010, E. Sérusiaux (LG 1333) & KT281700 & KT281658 & KT281612 & KT281752 \\
\hline 6 & canariensis & Ireland, Kerry, 2014, E. Sérusiaux (LG 3741) & KT281733 & KT281689 & KT281644 & KT281779 \\
\hline 7 & caperata & France, Réunion, 2009, N. Magain \& E. Sérusiaux (LG 962) & JQ735979 & JQ736012 & JQ735996 & KT281745 \\
\hline 8 & carolinensis & USA, North Carolina, 2013, B. Goffinet 11141 (LG 3302) & KT281724 & KT281680 & KT281635 & KT281786 \\
\hline 9 & ciliata & $\begin{array}{l}\text { Spain, Canary Is., Tenerife, 2011, P. van den Boom } 45673 \\
\text { (LG 2751) }\end{array}$ & KT281712 & KT281668 & KT281624 & - \\
\hline 10 & ciliata & Portugal, Azores, Pico, 2011, P.K. Divakar (LG 3099) & KT281715 & KT281671 & KT281627 & KT281762 \\
\hline 11 & ciliata & Spain, La Palma, 2013, E. Sérusiaux (LG 3406) & KT281713 & KT281669 & KT281625 & KT281780 \\
\hline 12 & ciliata & France, Brittany, 2013, A. Gérault (LG 3539) & KT281718 & KT281674 & KT281630 & KT281774 \\
\hline 13 & ciliata & France, Brittany, 2013, A. Gérault (LG 3542) & KT281714 & KT281670 & KT281626 & KT281772 \\
\hline 14 & ciliata & Ireland, Kerry, 2014, E. Sérusiaux (LG 3781) & KT281716 & KT281672 & KT281628 & KT281773 \\
\hline 15 & ciliata & Spain, Canary Is., Tenerife, 2014, E. Sérusiaux (LG 3830) & KT281719 & KT281675 & KT281631 & KT281775 \\
\hline 16 & ciliata & Rwanda, 2010, E. Sérusiaux (LG 1605) & KT281717 & KT281673 & KT281629 & KT281763 \\
\hline 17 & ciliata Colombia1 & Colombia (Moncada et al. 2014a, as S. microisidiata) & KC732607 & - & - & - \\
\hline 18 & ciliata Colombia2 & Colombia (Moncada et al. 2014a, as S. microisidiata) & KC732699 & - & - & - \\
\hline 19 & cyphellulata & $\begin{array}{l}\text { France, Réunion, 2009, N. Magain \& E. Sérusiaux } \\
\quad \text { (LG 1023) }\end{array}$ & JQ735980 & JQ736013 & JQ735997 & KT281748 \\
\hline 20 & dichotoma & France, Réunion, 2009, N. Magain \& E. Sérusiaux (LG 945) & JQ735981 & JQ736014 & JQ735998 & KT281743 \\
\hline 21 & dichotoma & France, Réunion, 2009, N. Magain \& E. Sérusiaux (LG 984) & JQ735982 & JQ736015 & JQ735999 & KT281746 \\
\hline 22 & duplolimbata & Rwanda, 2009, E. Sérusiaux (LG 919) & KT281696 & KT281654 & KT281651 & KT281741 \\
\hline 23 & duplolimbata & $\begin{array}{l}\text { France, Réunion, 2009, N. Magain \& E. Sérusiaux } \\
\quad \text { (LG 1040) }\end{array}$ & JQ735984 & JQ736001 & JQ736017 & KT281751 \\
\hline 24 & fuliginoides & France, Vosges, 2010, E. Sérusiaux (LG 1421) & KT281701 & KT281659 & KT281613 & KT281753 \\
\hline 25 & fuliginoides & $\begin{array}{l}\text { Spain, Canary Is., Gomera, 2012, E. Sérusiaux } \\
\text { (LG 3012) Type }\end{array}$ & KT281722 & KT281678 & KT281634 & KT281765 \\
\hline 26 & fuliginoides & France, Brittany, 2013, F. Séité (LG 3551) & KT281729 & KT281685 & KT281640 & KT281777 \\
\hline 27 & fuliginoides & United Kingdom, Devon, 2014, N. Magain (LG S4) & KT281738 & KT281694 & KT281649 & KT281785 \\
\hline 28 & fuliginoides & Ireland, Kerry, 2014, E. Sérusiaux (LG 3733) & KT281732 & KT281688 & KT281643 & KT281781 \\
\hline 29 & fuliginosa & Madagascar, 2008, E. Sérusiaux (LG 795) & KT281695 & KT281653 & KT281609 & KT281740 \\
\hline 30 & fuliginosa & France, Réunion, 2009, N. Magain \& E. Sérusiaux (LG 989) & KT281698 & KT281656 & KT281610 & KT281747 \\
\hline 31 & fuliginosa & Rwanda, 2010, E. Sérusiaux (LG 1611) & KT281702 & KT281660 & KT281614 & KT281754 \\
\hline 32 & fuliginosa & South Africa, 2010, B. Goffinet 10242 (LG 1952) & KT281703 & KT281661 & KT281615 & KT281755 \\
\hline 33 & fuliginosa & Portugal, Azores, Pico, 2011, P.K. Divakar (LG 3100) & KT281704 & KT281662 & KT281616 & KT281756 \\
\hline 34 & fuliginosa & Spain, Canary Is., Gomera, 2012, E. Sérusiaux (LG 3010) & KT281721 & KT281677 & KT281633 & KT281776 \\
\hline 35 & fuliginosa & France, Brittany, 2013, B. Bouffinier (LG 3537) & KT281727 & KT281683 & KT281638 & KT281766 \\
\hline 36 & fuliginosa & United Kingdom, Devon, 2014, N. Magain (LG S9) & KT281739 & - & KT281650 & KT281769 \\
\hline 37 & fuliginosa & Ireland, Kerry, 2014, E. Sérusiaux (LG 3729) & KT281731 & KT281687 & KT281642 & KT281768 \\
\hline 38 & limbata & Canada, British Columbia, T. Goward 09-246 (LG 3170) & KT281710 & - & KT281622 & - \\
\hline 39 & limbata & $\begin{array}{l}\text { Spain, Canary Is., Gran Canaria, 2011, E. Sérusiaux } \\
\text { (LG 2230) }\end{array}$ & KT281706 & KT281664 & KT281618 & KT281758 \\
\hline 40 & limbata & United Kingdom, Scotland, 2011, B. J. Coppins (LG 2690) & KT281707 & KT281665 & KT281619 & KT281759 \\
\hline 41 & limbata & $\begin{array}{l}\text { Spain, Canary Is., Gomera, 2011, P. van den Boom } 46085 \\
\text { (LG 2749) }\end{array}$ & KT281708 & KT281666 & KT281620 & KT281760 \\
\hline 42 & limbata & Portugal, Azores, Pico, 2011, P.K. Divakar (LG 3105) & KT281709 & KT281667 & KT281621 & - \\
\hline 43 & limbata & France, Brittany, 2013, A. Gérault (LG 3544) & KT281728 & KT281684 & KT281639 & KT281767 \\
\hline 44 & limbata & Portugal, Azores, Pico, 2014, E. Sérusiaux (LG 3868) & KT281711 & - & KT281623 & KT281761 \\
\hline 45 & macrophylla & France, Réunion, 2009, N. Magain \& E. Sérusiaux (LG 946) & JQ735985 & JQ736018 & JQ736002 & KT281744 \\
\hline
\end{tabular}


Table 1 (continued)

\begin{tabular}{|c|c|c|c|c|c|c|}
\hline & Epithet (Sticta) & Voucher & ITS & $\mathrm{mtSSU}$ & nuLSU & $R P B 1$ \\
\hline 46 & sublimbata & Congo RDC, 2009, E. Sérusiaux (LG 885) & JQ735986 & JQ736019 & JQ736003 & KT281771 \\
\hline 47 & sublimbata & $\begin{array}{l}\text { France, Réunion, 2009, N. Magain \& E. Sérusiaux } \\
\quad \text { (LG 1038) }\end{array}$ & KT281699 & KT281657 & KT281611 & KT281750 \\
\hline 48 & sylvatica & France, Brittany, 2013, A. Gérault (LG 3536) & KT281726 & KT281682 & KT281637 & KT281788 \\
\hline 49 & sylvatica & United Kingdom, Somerset, 2014, P. Wolseley (LG 3723) & KT281730 & KT281686 & KT281641 & KT281778 \\
\hline 50 & sylvatica & Ireland, Kerry, 2014, E. Sérusiaux (LG 3780) & KT281735 & KT281691 & KT281646 & KT281782 \\
\hline 51 & sylvatica & France, Vosges, 2014, E. Sérusiaux (LG 3837) & KT281736 & KT281692 & KT281647 & KT281783 \\
\hline 52 & umbilicariiformis & Rwanda, 2009, E. Sérusiaux (LG 925) & KT281697 & KT281655 & KT281652 & KT281742 \\
\hline 53 & variabilis & $\begin{array}{l}\text { France, Réunion, 2009, N. Magain \& E. Sérusiaux } \\
\quad \text { (LG 1037) }\end{array}$ & JQ735987 & JQ736020 & JQ736004 & KT281749 \\
\hline 54 & sp. $1(1)$ & Spain, Canary Is., Gran Canaria, 2011, E. Sérusiaux (LG 2229) & KT281705 & KT281663 & KT281617 & KT281757 \\
\hline 55 & sp. $1(2)$ & $\begin{array}{l}\text { Spain, Canary Is., Gomera, 2011, P. van den Boom } 46379 \\
\text { (LG 2752) }\end{array}$ & KT281720 & KT281676 & KT281632 & KT281764 \\
\hline 56 & sp. $1(3)$ & $\begin{array}{l}\text { Canada, British Columbia, 2009, T. Goward 09-246 } \\
\text { (LG 3173) }\end{array}$ & KT281723 & KT281679 & - & - \\
\hline 57 & $\begin{array}{l}\text { Pseudocyphellaria crocata } \\
\text { Outgroup }\end{array}$ & Spain, Canary Is., La Gomera, 2009, E. Sérusiaux (LG 688) & JQ735976 & JQ736009 & JQ735993 & KT281770 \\
\hline
\end{tabular}

GenBank accessions in bold refer to newly produced sequences

The single most likely phylogenetic tree resulting from the analysis of the matrix containing the two sequences of microisidiata ad. int. from Colombia (Moncada et al. 2014a) is presented in Fig. 1 with the bootstrap values of the ML analysis and the Bayesian PP values written above the branches when they are significant $(\geq 70 \%$ for maximum likelihood analysis and $\geq 0.95$ for the Bayesian analysis). The clade including $S$. ciliata, from the tree resulting from the analysis of the matrix without the two accessions from Colombia, is figured as an inset in Fig. 1 to highlight the difference in support values in this clade when they are not present. Branch support of other lineages were not significantly affected when these two accessions were included, while those inside the clade that comprise them were.

The phylogenetic tree resolved two strongly supported lineages: (1) the large and usually luxuriant species from Reunion including green (S. caperata and $S$. variabilis) and blue photomorphs (S. macrophylla) or both (S. dichotoma), and (2) the isolated Sticta cyphellulata from Reunion, resolved with strong support as sister to all other species including those dealt with in this paper. Three clades can be recognized in the latter lineage:

- one with $S$. canariensis, resolved with strong support as sister to a group comprising $S$. beauvoisii, $S$. carolinensis, and S. sublimbata;

- one including the resurrected epithet $S$. ciliata and S. fuliginoides sp. nov., with strong support only in the Bayesian analysis;

- one resolved in two well-supported groups including S. duplolimbata, S. sylvatica, and Sticta sp. 1 for the first one, and S. ambavillaria, S. atlantica sp. nov., S. fuliginosa, S. limbata, and S. umbilicariiformis for the second one.

The MP phylogenetic tree of our own accessions within a large data set of all species recognized in Colombia (Moncada et al. 2014a) resolved the following relationships (data not shown): S. atlantica sp. nov. is resolved within the $S$. humboldtii clade, S. canariensis in the eponym clade, $S$. ciliata within the $S$. fuliginosa clade/subclade $S$. gyalocarpa, S. fuliginoides within the $S$. fuliginosa clade and in the eponym subclade, S. fuliginosa and S. limbata within the S. humboldtii clade, and finally $S$. sylvatica within the $S$. kunthii clade.

TCS haplotype networks (Fig. 2) were produced for the duo S. fuliginosa/S. limbata (49 accessions incl. those retrieved from GenBank and resolved in that group), for $S$. fuliginoides (32 accessions incl. those retrieved from GenBank and resolved in that species) and S. ciliata (29 accessions incl. both accessions under microisidiata ad. int. in Moncada et al. 2014a). Our accession of S. ciliata from Rwanda is excluded from the latter under the $90 \%$ limit assigned to the analysis and is not shown.

With the most widely used lichen flora, at least for oceanic species (The Lichens from Great Britain and Ireland, Smith et al. 2009), the specimens collected in this study are resolved as follows:

- those easily identified as $S$. canariensis are resolved as a single entity;

- those identified as S. fuliginosa are resolved into four distinct entities: $S$. atlantica sp. nov., the ressurected S. ciliata, $S$. fuliginoides sp. nov., and $S$. fuliginosa s. str.; 


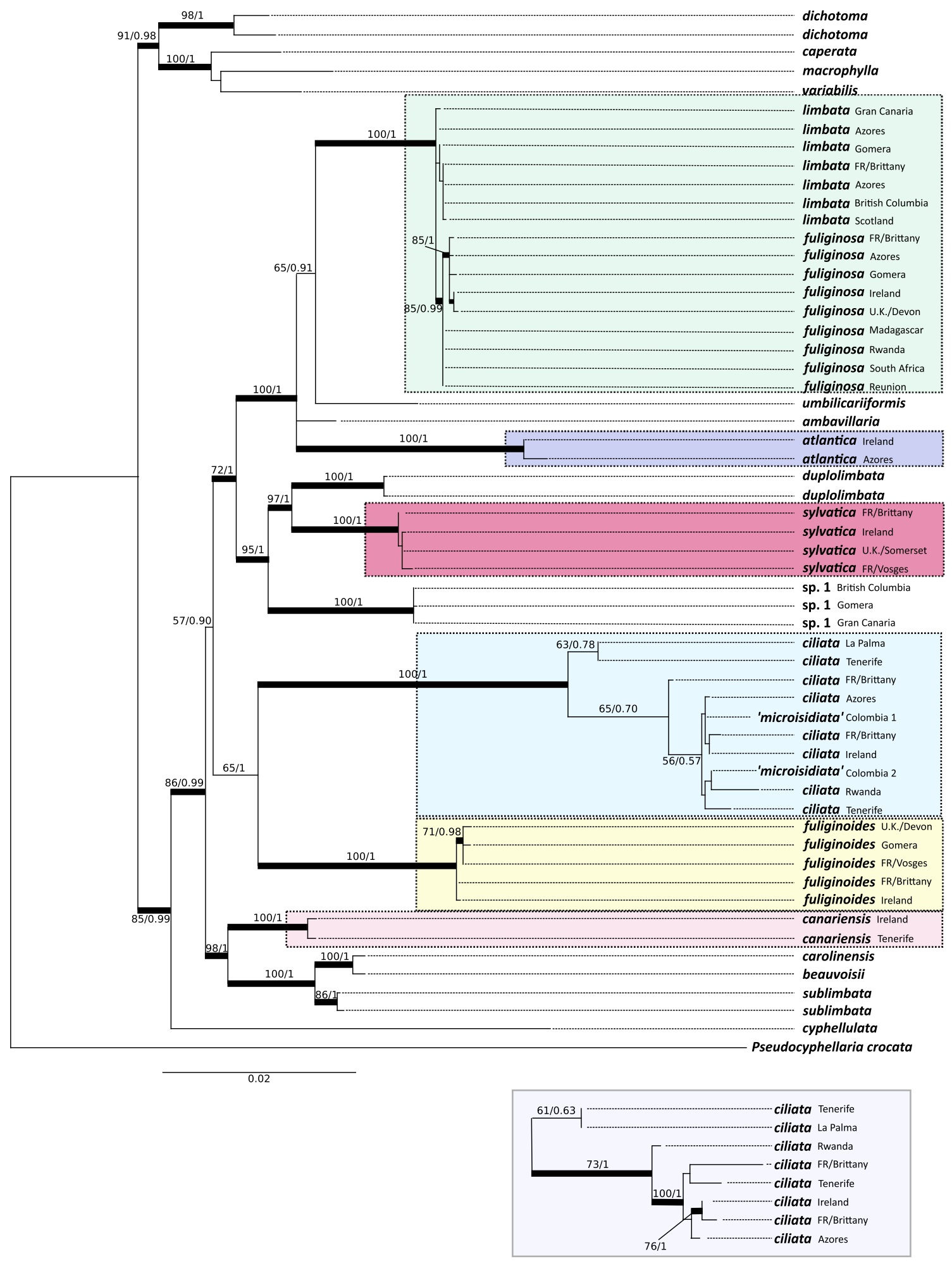

Fig. 1 Single most likely phylogenetic tree obtained from inferences of 4-loci molecular data (ITS, nuLSU, mtSSU, and RPB1). Branches in bold are those that obtained support greater or equal than 70 from maximum likelihood bootstrap and greater or equal than 0.95 for Bayesian posterior probabilities; values above branches represent ML bootstrap and
Bayesian PP values, respectively. Inset below concerns the clade comprising $S$. ciliata when both accessions from Colombia (represented only by ITS data) are excluded. The seven species present in continental Europe are highlighted with specific colors 
Fig. 2 Haplotype networks for ITS accessions of Sticta limbata and $S$. fuliginosa, S. fuliginoides and $S$. ciliata. Circles represent haplotypes. The size of each circle is proportional to the number of individuals sharing this haplotype. Each bar between circles in the network represents a single mutation step, and each dot is an additional change

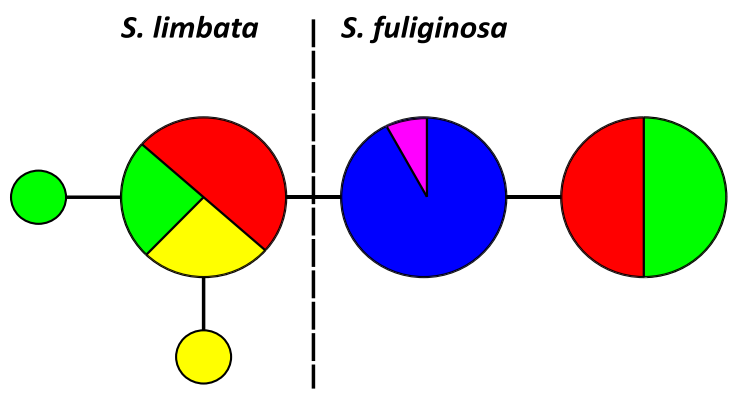

S. fuliginoides
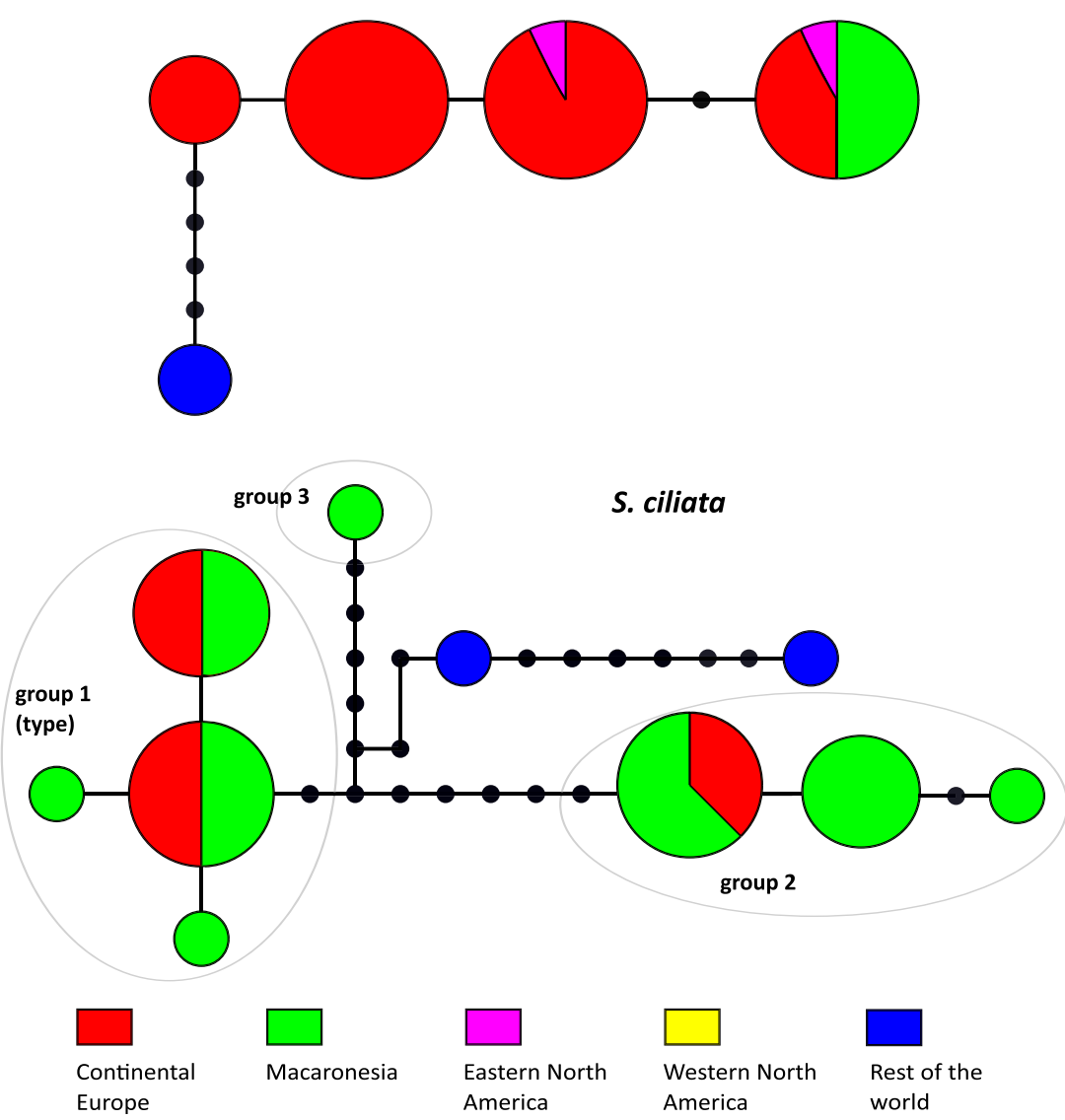

- those identified as $S$. sylvatica are resolved in a single entity $S$. sylvatica s. str., although $S$. atlantica sp. nov. might have been confused with it in Macaronesia.

Quite interestingly, the longest branches, representing the most genetically distinct entities, are those that were not recognized, e. g., S. atlantica sp. nov., S. ciliata, and S. fuliginoides sp. nov. Further, S. fuliginosa s. str. and S. limbata, two species that any lichenologist would immediately recognize as different as the first one is isidiate and the second sorediate, are not resolved as two supported entities with the 4-loci inferences. They differ by a single substitution in the ITS haplotype network.
All data retrieved from GenBank under the epithets canariensis, fuliginosa, limbata, and sylvatica have been reevaluated and their correct taxonomical assignment is presented in Table 2.

No compounds were detected in the TLC analyses performed.

\section{Geographical data}

All data that could be confirmed on the basis of ITS data yielded a reassessment of the distribution of all species, which is summarized in Table 3. 
Table 2 Status of accessions from GenBank under the four epithets used for species in continental Europe: Sticta canariensis, S. fuliginosa, S. limbata, and $S$. sylvatica

\begin{tabular}{|c|c|c|c|c|}
\hline GenBank accession $n^{\circ}$ & Origin & Identification in original publication & Original publication & Status obtained in this study \\
\hline AB239395 & Japan & fuliginosa & Takahashi et al. 2006 & fuliginosa \\
\hline AY124095 & China & fuliginosa & Lohtander et al. 2002 & $\begin{array}{l}\text { Undescribed species, also detected in the } \\
\text { Canary Islands and Western North America }\end{array}$ \\
\hline AY173391 & USA/Oregon & limbata & McDonald et al. 2003 & $\begin{array}{l}\text { limbata but the only accession of that species } \\
\text { with the ITS of fuliginosa }\end{array}$ \\
\hline AY173387 & Eastern USA & fuliginosa & McDonald et al. 2003 & fuliginoides \\
\hline AY173388 & Eastern USA & fuliginosa & McDonald et al. 2003 & fuliginoides \\
\hline AY173389 & Eastern USA & fuliginosa & McDonald et al. 2003 & fuliginoides \\
\hline DQ419943 & Canada/B.C. & fuliginosa & Cornejo et al. 2009 & Undescribed species \\
\hline DQ419944 & Canary Is. & canariensis & Cornejo et al. 2009 & canariensis \\
\hline JN857309 & $\begin{array}{l}\text { USA/ } \\
\text { California }\end{array}$ & limbata & Fedrowtiz et al. 2012 & limbata \\
\hline JX064536 & Eastern USA & sylvatica & Hodkinson et al. 2014 & fuliginosa \\
\hline KC011069 & U.K./Wales & fuliginosa & Moncada et al. 2013a & fuliginoides \\
\hline KC732518 & Columbia & sylvatica & Moncada et al. 2014a & sylvatica \\
\hline KC732574 & Columbia & sylvatica & Moncada et al. 2014a & sylvatica \\
\hline KC732581 & Columbia & sylvatica & Moncada et al. 2014a & sylvatica \\
\hline KC732454 & U.K./Wales & fuliginosa & Moncada et al. 2014a & fuliginoides \\
\hline KC732709 & Colombia & fuliginosa & Moncada et al. 2014a & fuliginoides \\
\hline KC732607 & Colombia & « microisidiata Magain et al. » ined & Moncada et al. 2014a & ciliata \\
\hline KC732699 & Colombia & « microisidiata Magain et al. » ined & Moncada et al. 2014a & ciliata \\
\hline
\end{tabular}

\section{Taxonomy}

The taxonomy of isidioid species of Sticta in Europe that is currently used in all modern Floras was already established by Delise (1826) in his seminal taxonomical work on the genus, and eventually confirmed by Degelius (1935) in his work on oceanic lichen species in Europe.

Unlike in other emblematic genera such as Cladonia and Peltigera, very few epithets have been validly published for European representatives of the genus. Indeed, besides those used or introduced by Delise (1826: canariensis, dufourii, fuliginosa, limbata, and sylvatica) only three are available at species level (Sticta ciliata Tayl., S. fimbriata Tayl., and S. elegans Deak), and all have been reduced into synonymy with $S$. dufourii Delise by Galloway (1995), who was, at that time, still doubtful about the true nature of the duo of photomorphs formed by $S$. canariensis and $S$. dufourii.

Delise (1826) has been working on collections made all over the world by several most famous collectors, such as J.B.G.M. Bory de Saint-Vincent, A.M.F.J. Palisot de Beauvois (to whom Sticta beauvoisii was dedicated), J. A. Mougeot (to whom Sticta mougeotiana was dedicated, a species now referred to Pseudocyphellaria), C. Gaudichaud-Beaupré (to whom $S$. gaudichaldia was

Table 3 Distribution of the species of Sticta recognized in continental Europe by this study and confirmed out of that area by the ITS barcode

\begin{tabular}{|c|c|c|c|c|c|c|}
\hline Name & France Vosges & France Brittany & U.K. & Ireland Kerry & Macaronesia & Others \\
\hline atlantica & - & - & - & $\mathrm{X}$ & Azores & - \\
\hline canariensis & - & $\mathrm{X}$ & $\mathrm{X}$ & $\mathrm{X}$ & Canary Is, Madeira, Azores & - \\
\hline ciliata & - & $\mathrm{X}$ & - & $\mathrm{X}$ & Canary Is, Azores & $\begin{array}{l}\text { Hawaii archipelago, Central and } \\
\text { South America, and Rwanda }\end{array}$ \\
\hline fuliginosa & - & $\mathrm{X}$ & $\mathrm{X}$ & $\mathrm{X}$ & Canary Is., Azores & Widespread in both hemispheres \\
\hline fuliginoides & $\mathrm{X}$ & $\mathrm{X}$ & $\mathrm{X}$ & $\mathrm{X}$ & Canary Is. & Eastern North America and Colombia \\
\hline limbata & - & $\mathrm{X}$ & $\mathrm{X}$ & $\mathrm{X}$ & Canary Is., Azores & Western North America \\
\hline sylvatica & $\mathrm{X}$ & $\mathrm{X}$ & $\mathrm{X}$ & $\mathrm{X}$ & - & Colombia \\
\hline
\end{tabular}


dedicated), and others. After his military career, he retired in western France (Dept. Calvados) at a time when epiphytic Lobarion communities were luxuriant - he mentioned that he could collect S. sylvatica "aux environs de Paris", a species for which he provided a quite accurate description as the thallus is said to be (p. 86, translated from Latin) "deeply laciniate with sub-truncate to rounded lobes". More details on his life and botanical work can be found in Galloway and James (1986).

He found and described $S$. dufourii, the cyanomorph of $S$. canariensis, and further collected $S$. sylvatica, S. limbata and S. fuliginosa. His description of the latter is quite interesting as he actually describes, at least in parts, material that is here assigned to $S$. ciliata: indeed, he describes thalli with ( $\mathrm{p}$. 75 , translated from French) "the lobes edges often eaten and undivided only in young individuals" and apothecia with cilia, developed near the thallus edges. Nowadays, in suitable habitats in Western France, S. ciliata is found with laceratestrongly damaged thalli and ciliate apothecia (Fig. 5a-b). Delise clearly referred to the original description of S. fuliginosa, but did not realize that two species were involved. This confusion has lasted for almost two centuries.

Besides the cyanomorph of S. canariensis, Degelius (1935) distinguished two isidiate species (p. 171, translated from German):

- S. sylvatica has a larger and thicker thallus, with a shiny upper surface and deep folds to which the always very small isidia are attached.

- S. fuliginosa has a small, rounded, thin, not or only slightly indented thallus, with a matte or slightly shiny upper surface, mostly not wrinkled, with numerous and often large, and leaf-like isidia, which are usually scattered over the whole surface.

Within S. fuliginosa, Degelius further distinguished two forms: the typical one, always with a matte upper surface and an involute margin, with isidia uniformly distributed over the whole thallus; and the f. obvoluta (Del.) Zahlbr. (an epithet based on material from Venezuela: Delise 1826; see comments on this material in Galloway 1995: 160-161) with a slightly shiny thallus, slighted wrinkled and isidia mainly located on the folds. Although Degelius seemed confident in the characters diagnostic for distinguishing $S$. sylvatica from S. fuliginosa, the introduction of the intermediate form obvoluta confused his taxonomical treatment of the isidioid species of Sticta in Europe. Indeed, the distinction between these two species was a matter of debate in several earlier papers such as Harmand (1909) and Anders (1928) who concluded that these taxa should better be treated as varieties.

Nevertheless, the recognition of two taxa as delimited by Degelius characters was widely accepted, first as varieties (Poelt 1963; Lambinon 1969; Ozenda and Clauzade 1970) and eventually as species following Poelt (1969) (Jørgensen and Tønsberg 2007; Smith et al. 2009; Wirth et al. 2013). Both species were assumed to be widespread, or even subcosmopolitan. Quite interestingly, the taxonomy of this duo was never re-evaluated for European populations, although both species received much attention in environmental monitoring, for air quality as well as forests management and conservation.

Our results demonstrate that the genus in Europe is much more diversified than expected, as sampling in four regions in France, the United Kingdom, and Ireland could unveil five different species amongst specimens producing isidia. The two old and validly published names $S$. fuliginosa and S. sylvatica have been re-evaluated on the basis of careful examination of type collections preserved in OXF (Fig. 3). A validly published epithet, so far considered a synonym of $S$. canariensis, is resurrected (S. ciliata; type collection in BM; Fig. 3), and two species are described as new for science as no validly published epithets could be found for them. Each European species is described in this section, together with preliminary assessments of their distribution.

\section{The species}

Sticta atlantica Magain \& Sérus., sp. nov. (Fig. 4)

Mycobank \# 813823

Species of Sticta distinguished from other isidiate species in Western Europe with a thallus lichenized with a cyanobacterium by its suborbicular lobes and upper surface with typically regular or irregular swellings or ridges on which isidia start their development to form coralloid stipitate masses.

= Sticta fuliginosa auct. p.p., non (Hoffm.) Ach.

?=Sticta sylvatica auct. p.p., non (Huds.) Ach.

Type: Portugal, Azores archipelago, Pico Is., Parque Forestal along the road to Prainha de Cima, N 38 29'19.62" W $28^{\circ} 14^{\prime} 42.18^{\prime \prime}$, alt. $240 \mathrm{~m}$, July 2014, plantations of Pinus with fragments of natural vegetation, E. Sérusiaux LG DNA 3858, (LG-holotypus; AZU—isotypus).

Thallus first flabellate or palmate as the lobes forming a single thallus develop from a central point on a short and evanescent stipe (pseudostipe) eventually becoming suborbicular or, more rarely, irregular, 4-7 cm across, sometimes forming large colonies that can reach c. $15 \mathrm{~cm}$ across, subcoriaceous when wet and usually papyraceous and brittle when dry; lobes with 1-2 branching, pleurotomous to polytomous, rarely irregular. Lobes suborbicular in typical thalli, rarely irregular in outline, $1.0-1.8 \mathrm{~cm}$ width, adnate to slightly ascending, imbricate and overlapping, plane or undulating, with apices rounded, plane to slightly revolute, crenate to lacerate, margin not thickened. Upper surface costate, irregular, with regular or irregular swellings or grooves, brownish or bluish grey (these two color types can occur side by side), of the same color when wet or dry, matte or somewhat 
Fig. 3 Types collections of the three European isidiate species of Sticta that are already described. a-d Sticta ciliata. a Lectotype of Sticta ciliata Tayl. (BM), the lower specimen enlarged in $\mathbf{b}$, and a well-preserved ciliate lobe enlarged in $\mathbf{c}$ (between red arrows). d similar thalli pictured on Faial Is., Azores (July 2014, E. Sérusiaux s.n., LG) and very much like the type of $S$. fuliginosa f. ciliata Degel. e-f Sticta fuliginosa (Hoffm.) Ach, epitype (OXF). $\mathbf{f}$ Detailed view of a lobe with apothecia. $\mathbf{g}-\mathbf{h}$ Sticta sylvatica (Huds.) Ach., epitype (OXF)
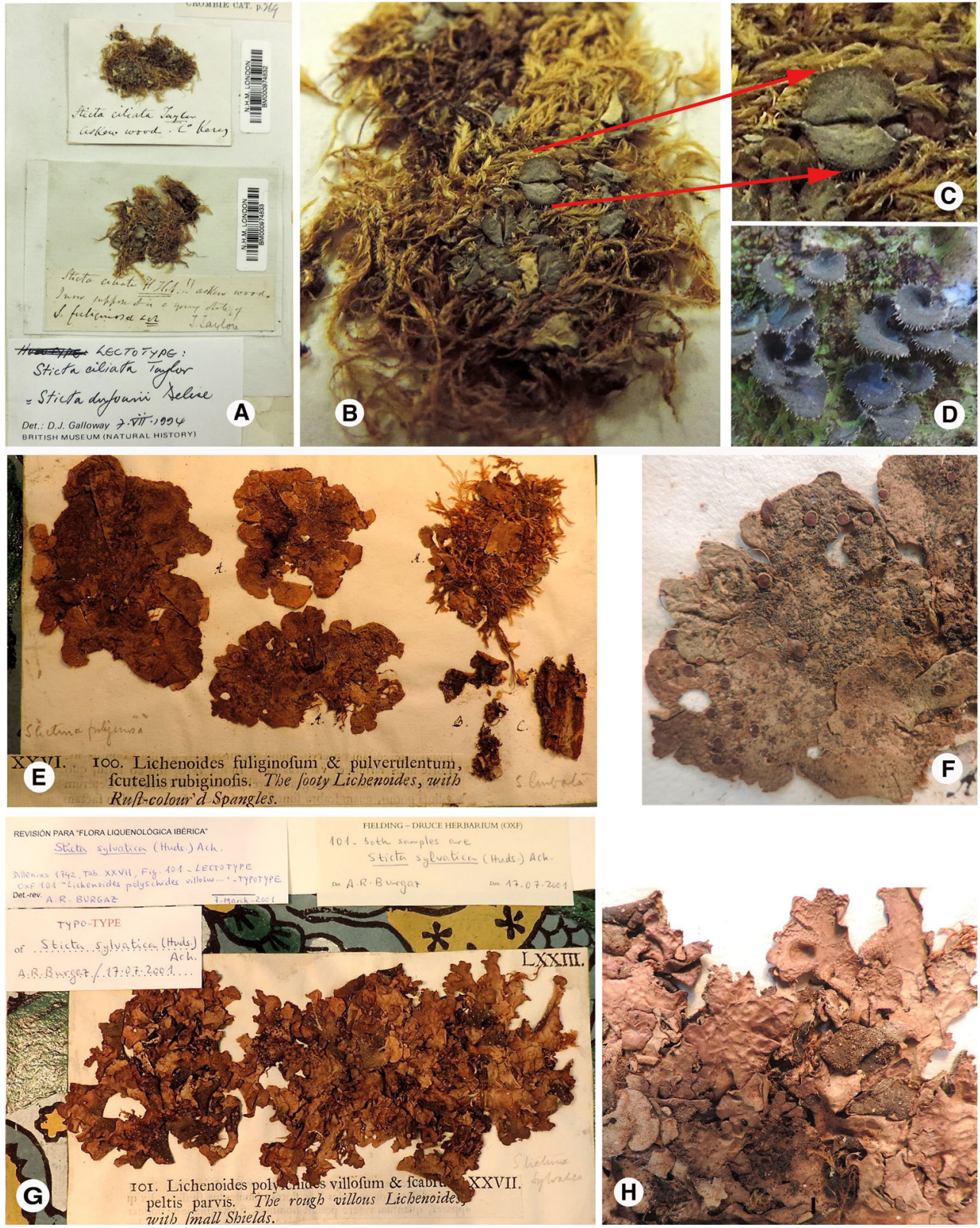

glossy, maculae yellowish rather distinct on bluish grey thalli, sparse and not confined to certain parts of the thallus. Cilia absent, or rarely found on regenerating lobules, whitish, simple, $<0.5 \mathrm{~mm}$ long. Isidia always present, marginal or laminal, when marginal forming a marginal string of coralloid or subsquamiform minute structures, sometimes becoming distinctly stipitate, when laminal, always starting their development on the swellings or ridges, and forming stipitate (stipe cylindrical or subapplanate, $0.2-0.4 \mathrm{~mm}$ long and c. $0.1 \mathrm{~mm}$ in diam.) coralloid to corymbose masses that can reach $1 \mathrm{~mm}$ in diam., coarse or delicate, usually shining, of the same color as the thallus on which they grow. Lower surface foveolate to scrobiculate, white, cream-colored to brownish, with primary tomentum always present, sparse towards the margin but sometimes becoming very dense towards the center; primary tomentum made of distinct fasciculate to penicillate hairs, easily distinguished from one another in young lobes, eventually forming spongy masses, especially towards the center, soft to rough, white to grey or reddish brown. Cyphellae always present, abundant, round to slightly irregular, rather angular on old lobes, 25-40 per $\mathrm{cm}^{2}$, but reaching 50 per $\mathrm{cm}^{2}$ towards the margins, cupuliform to urceolate with wide pore, the largest ones reaching $1.5-1.8 \mathrm{~mm}$ in diam., much smaller towards the margin (less than $0.5 \mathrm{~mm}$ in diam.), prominent, with an erect, white or cream-colored margin. Apothecia and pycnidia never produced.

Upper cortex paraplectenchymatous, 25-30 $\mu \mathrm{m}$ high, with 3-4 layers of rounded to isodiametric cells, $8-12 \mu \mathrm{m}$ in diam. 
Fig. 4 Sticta atlantica Magain \& Sérus., sp. nov. a-b Specimen from Ireland/Kerry (Feb. 2014, E. Sérusiaux s.n., LG). a Thallus on fallen tree. b Detail view of the thallus surface with irregular swellings on which isidia develop. $\mathbf{c}-\mathbf{h}$ Type collection from Pico Is., Azores (July 2014, E. Sérusiaux s.n., LG) . c Upper surface with laminal swellings and marginal coralloid isidia. $\mathbf{d}$ Lower surface with conspicuous cyphellae. e Lower surface with primary tomentum agglutinated in fibrillose to penicillate fasciles. $\mathbf{f}-\mathbf{h}$ Conidiogenous cells along the primary tomentum hyphae. $\mathbf{g}$ With Woronin bodies easily distinguished. Scale bars: b $1 \mathrm{~mm}, \mathbf{c}-\mathbf{d} 2 \mathrm{~mm}$, e $0.5 \mathrm{~mm}, \mathbf{f}-\mathbf{h}$ $10 \mu \mathrm{m}$ (scale in $\mathrm{h}$ )
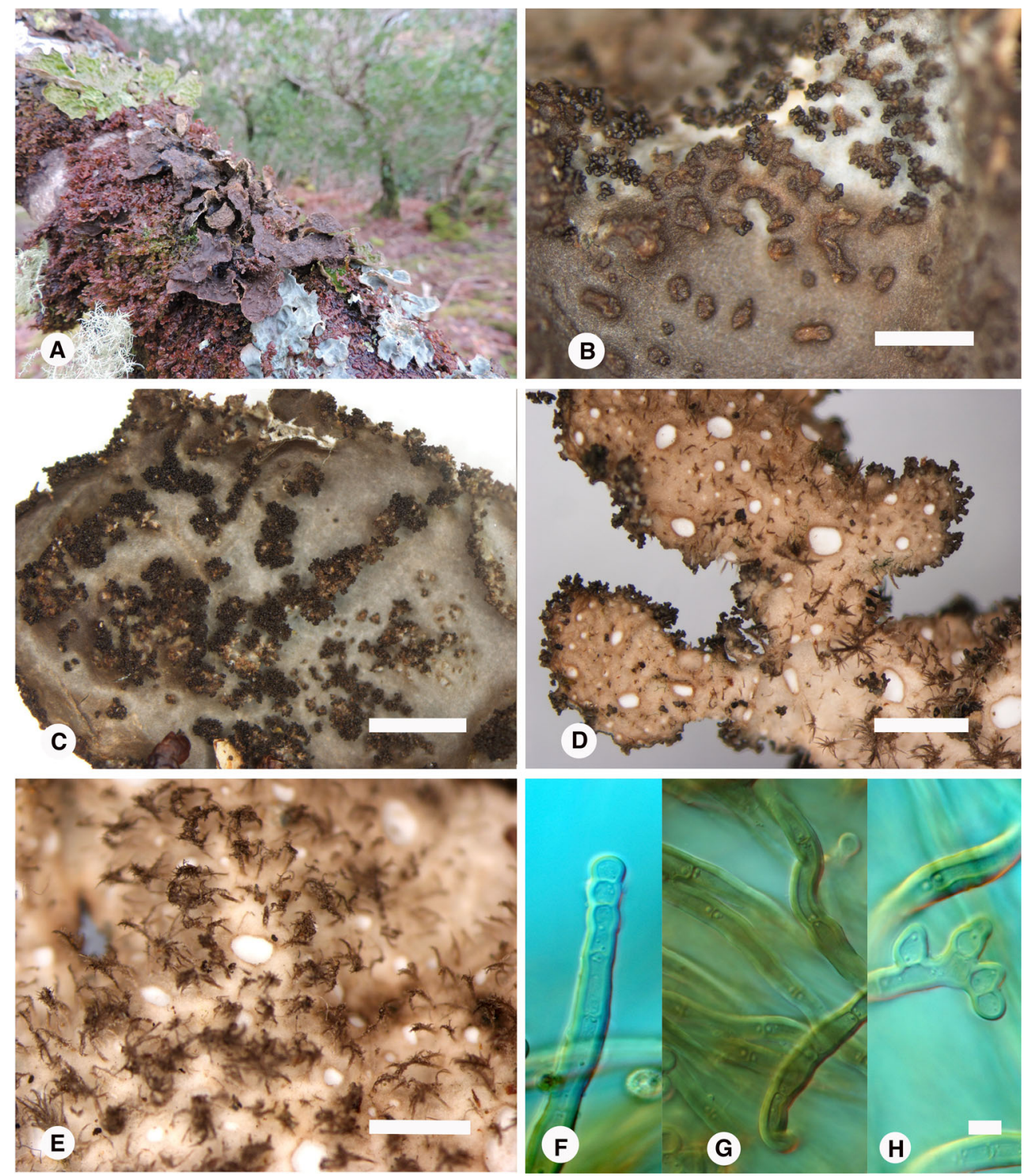

and a $1.5 \mu \mathrm{m}$ thick wall, sometimes with an upper layer of smaller cells with their outer wall thickened to $4 \mu \mathrm{m}$. Photobiont layer 40-50(-70) $\mu \mathrm{m}$ high containing Nostoc colonies, forming rather compact, ovoid masses, tightly encompassed by hyphae forming rounded to angular cells, and thus designing a single layer wrapping up the Nostoc cells; no differences in the Nostoc cells detected between brown and bluish gray thallus. Medulla lax to compact, 60 $80 \mu \mathrm{m}$ high.

Lower cortex paraplectenchymatous, $15-25 \mu \mathrm{m}$ high, with $2-3$ layers of rounded to isodiametric cells, $8-12 \mu \mathrm{m}$ in diam. and a $1.5-3 \mu \mathrm{m}$ thick wall. Lower primary tomentum agglutinated in fascicules that form large, but not compact fibrillose to penicillate masses, looking-like rhizines, with free and interwined, cylindrical hyphae, with a $2-2.5 \mu \mathrm{m}$ thick wall, usually with typical Woronin bodies seen near the septa; these hyphae develop a conidiogenous process either terminally or laterally in branched and short hyphae; conidia almost always spherical, 5-7 $\mu \mathrm{m}$ in diam with a $1 \mu \mathrm{m}$ thick wall. Lower secondary tomentum sometimes indistinct, made of budding cells on the lower cortex surface, forming moniliform assemblages of $2-10$ cells, $5-10(-12) \mu \mathrm{m}$ in diam and with a c. $1 \mu \mathrm{m}$ thick wall. Cyphellae membrane made of a layer of rounded cells (4-8 $\mu \mathrm{m}$ in diam.) without any papillae.

No substances detected by TLC.

Etymology: the epithet of this new species is chosen to evoke its distribution, in the hyper-oceanic localities in the NE Atlantic region.

Ecology: epiphytic on branches in Quercus woodland, in the most famous Tomies wood in SW Ireland (Giavarini 2012); and on branches or small trees in remnants of the laurisilva in the Azores (only known on Pico Is.). The laurisilva of the Azores and the whole Macaronesia hosts an impressive number of species of Peltigerales, with several 
recently recognized species or endemics (examples with Lobaria: Cornejo and Scheidegger 2010, or with Nephroma: Sérusiaux et al. 2011).

Distribution: known from Ireland/Kerry and the Azores (Pico Is.), only abundant in the Azores, even in heavily disturbed remnants of original vegetation, where it thrives with S. ciliata. With the data currently available, the species has a hyper-oceanic distribution, quite similar to other rare species such as Cladonia angustiloba Ahti \& Aptroot known from the Azores and Madeira and recently found in the Faroe Islands (Ahti and Stenroos 2012), Degelia ligulata P.M. Jørg. \& P. James, known from W Scotland, Wales, W Ireland and Macaronesia, and Topeliopsis azorica (P. James \& Purvis) Coppins \& Aptroot known from W Scotland and the Azores (Smith et al. 2009).

Notes:

1. Amongst European species, $S$. atlantica is easily distinguished by its suborbicular lobes, with a crenate to lacerate margin and upper surface with typically regular or irregular swellings or ridges on which isidia start their development to form coralloid stipitate masses. The species can be confused with $S$. fuliginosa, which mainly differs by its larger lobes $(1.5-3 \mathrm{~cm}$ wide in welldeveloped specimens) not developing small swellings on which isidia start their development, although isidia may develop only on the ridges of the scrobiculatefoveolate surface in this species.

2. Within the first phylogeny of the genus provided by Moncada et al. (2014a) based on a single locus (ITS) and focusing on species from Colombia, this new species is resolved within the $S$. humboldtii clade, a diverse group in the Andes; $S$. atlantica differs from all other species resolved in that group by at least three substitutions in ITS1 and seven in ITS2. A multi-loci phylogeny is, however, needed before the assignement of $S$. atlantica to that clade can be confirmed.

3. Two collections slightly differ from the typical haplotype, detected in the Azores as well as in Ireland: one from Ireland differs by one substitution in ITS1 and three in ITS2 while a single one from Pico differs by two substitutions and one indel in ITS1. This variation is considered as intraspecific.

Selected specimen examined: Ireland, Kerry, W of Lake Killarney, Tomies Wood, $52^{\circ} 02^{\prime} 12^{\prime \prime} \mathrm{N} 09^{\circ} 43^{\prime} 60^{\prime \prime} \mathrm{W}$, alt. 90 100 m, Feb. 2014, disturbed Quercus woodland, E. Sérusiaux s.n. (LG).

Sticta canariensis (Flörke) Delise, Mém. Soc. Linn. Calvados 2: 114, 1825 (Fig. 5)

MycoBank \# 406113

Pulmonaria canariensis Flörke, Mag. Ges. Naturf. Fr. Berlin 2: 127, 1890
Type: Spain, Canary Is., Tenerife, forêt de Laguna, Bory de Saint-Vincent (BM-lectotype !; designated by Galloway, Nova Hedwigia 61:152, 1995)

$=$ Sticta dufourii Delise, Mém. Soc. Linnéenne Calvados 2: 78, pl. 6, Fig. 22 (1826)

Type: Spain, Canary Is., M. Defour (PC-Lenormand, lectotype; designated by Galloway, Nova Hedwigia 61:166, 1995)

= Sticta fimbriata Taylor, London Journal of Botany 6: 180 (1847)

Type: Ireland: in woods near Killarney, T. Taylor (?FH; not seen by Galloway 1995); material in BM (!) annotated Sticta fimbriata nobis, Hyde's Cottage 17 Aug. 1836, possibly a syntype

= Sticta elegans Deak, in W. Mudd, A Manual of British Lichens: 89 (1861)

Type: England, on rocks and stems of ivy. Rock Walk, Ilsham, near Torquay, Devonshire, W.A. Leighton (BM-lectotype !; designated by Galloway, Nova Hedwigia 61: 169, 1995)

Cyanomorph.

Thallus usually palmate or irregular in outline, $1-6 \mathrm{~cm}$ in diam., in suitable conditions forming large colonies made of several thalli intermingled one with another and overlapping, usually thin and brittle when dry, but some populations develop rather stiff thalli, sometimes with a distinct, short, and robust stipe, with branched lobes (with 2-4 ramifications per main lobe), branching anisotomous or polytomous. Lobes suborbicular to ligulate in outline, overlapping, slightly ascending, especially when dry, plane to slightly involute, with rounded to irregular apices, margins regularly and minutely dissected, even at early stages of development, soon developing palmate or shortly stipitate phyllidia, $0.5-0.8(-1.2) \mathrm{mm}$ long, dichotomously and several times branched, forming dense, $+/-$ flattened, shortly stipitate and imbricate, minute and gently indented lace-like clusters at the thallus margins and sometimes invading parts or the whole thallus surface, of the same color as the thallus or darker. Upper surface smooth or rarely scrobiculate or foveolate, matte, dark bluish brown to dark brown when wet, becoming slate dark bluish when dry, typically marbled and maculate, especially on older parts, sometimes remaining dark brown, cilia absent. Lower surface foveolate to scrobiculate, orange to brown-colored; primary tomentum absent on the edges of young lobes and sometimes on old lobes, usually abundant throughout, pubescent to slightly spongy; no secondary tomentum detected. Cyphellae always present on the lower surface of main lobes, sometimes present on the lower surface of phyllidia, dispersed, rounded or angled, $5-15$ per $\mathrm{cm}^{2}, 0.3-0.6(-1) \mathrm{mm}$ in diam., immersed to erumpent, margin whitish to orange-brown. Apothecia and pycnidia never produced.

Upper cortex paraplectenchymatous, 20-25 $\mu \mathrm{m}$ high, homogeneous with 2-3 layers of rounded to isodiametric cells 
Fig. 5 Sticta canariensis (Flörke) Delise. a-b Chloromorph photographed in the field in Madeira (Apr. 2007, M. Dewald, A. Hambuckers \& E. Sérusiaux). a Close-up to dichotomous lobes with numerous apothecia. $\mathbf{c}-\mathbf{f}$ Cyanomorph, also known as S. dufourii (France/Brittany, Nov. 2013, A. Gérault s.n., LG). c Thallus with maculate upper surface and marginal phyllidia. d Microscopic view of Nostoc cells embedded into a

paraplectenchamatous layer within the thallus. e-f Upper and lower side of the same lobe, showing the typically maculate upper surface and marginal phyllidia (that bear minute cyphellae on their lower surface). Scale bars: c, e, f $2 \mathrm{~mm}, \mathbf{d} 10 \mu \mathrm{m}$
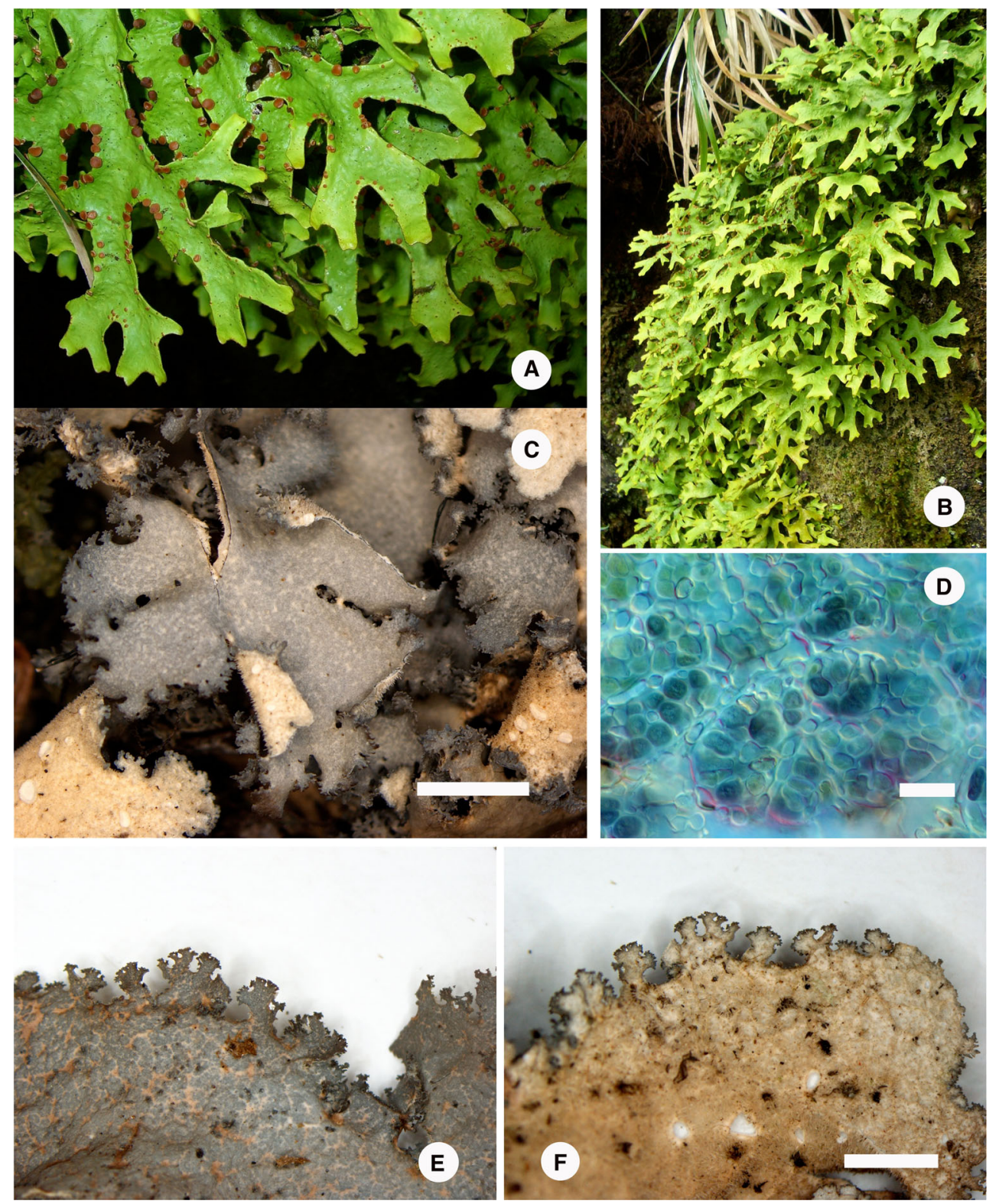

(8-15 $\mu \mathrm{m}$ in diam) or with an upper layer made of a single layer of small cells (5-8 $\mu \mathrm{m}$ in diam). Photobiont layer c. 50$90 \mu \mathrm{m}$ high, Nostoc colonies, forming rather compact, ovoid masses, 40-70×35-45 $\mu \mathrm{m}$, tightly encompassed by hyphae forming rounded to angular cells, and thus designing a single layer wrapping up the Nostoc cells. Medulla compact, whitish, c. $50 \mu \mathrm{m}$ high, with hyphae walls 3-4 $\mu \mathrm{m}$. Lower cortex paraplectenchymatous, $20-30 \mu \mathrm{m}$ high, with 2-3 layers of rounded to isodiametric cells $(10-15 \mu \mathrm{m})$. Lower primary tomentum formed of bunches of cylindrical hyphae, 0.1$0.3 \mathrm{~mm}$ long, agglutinated to each other or not, usually easily separated apart in water preparation, made of elongate cells with thick walls (lumina: 8-14×4-5 $\mu \mathrm{m}$; walls: $1.5-2 \mu \mathrm{m}$ thick). Cyphellae membrane made of 1-4 layers of irregular cells, developing ovoid to irregularly inflated cells, $6-10 \times 4$ $5 \mu \mathrm{m}$, at the cyphellae surface where they can be isolated one from another.

No substances detected by TLC.

Chloromorph

Thallus formed of bunches of elongate and dichotomously branched (branching mode rarely anisotomous or polytomous) lobes, forming large colonies in suitable conditions made of several thalli intermingled one with another and overlapping, or with lobes more adjacent than imbricate, up to $15 \mathrm{~cm}$ long and c. $10 \mathrm{~cm}$ large, 2-4 ramifications per main lobe, subcoriaceous and rather resistant. Lobes ligulate to mostly lacinate, horizontal or ascending when growing on subvertical substrate (tree or outcrop), plane to involute, with 
apices truncate to spathulate, involute to undulate, margins entire and not thickened, internode $0.3-1.0 \mathrm{~cm}$. Upper surface smooth, green to vivid green or yellowish green when wet, becoming pale orange brown when dry or in herbarium conditions, matte, but shiny when wet, without tomentum, maculae or cilia. Lower surface smooth, cream-colored to pale brown, becoming much darker towards the center of the thallus; primary tomentum present, sparse throughout, rather thick and thinner towards the margins, pubescent to arachnoid, soft, cream-colored to brownish black towards the center; no secondary tomentum detected. Cyphellae always present, abundant, dispersed, rounded or rarely irregular or angular, 20-40 per $\mathrm{cm}^{2}$ in the mature parts of the lobes, less dense (c. 10-20 per $\mathrm{cm}^{2}$ towards the apices), $0.3-0.4(-0.6) \mathrm{mm}$ in diam, prominent, mostly at tomentum level, margin elevated and sligthly involute, cream-colored to dark brown, basal membrane white. Apothecia usually abundant, rarely absent, laminal or submarginal, sessile to rarely subpedicellate, always strongly constricted at their base, without any lobe invagination underneath, $0.3-0.5(-0.7) \mathrm{mm}$ in diam., with a disc chamoiscolored to orange- to reddish-brown, concave when young, with prominent margin in young apothecia, cream-colored, always much paler than the disc. Pycnidia immersed, with a brown-black wall.

Upper cortex paraplectenchymatous, 35-45 $\mu \mathrm{m}$ thick, made of two differentiated layers, the upper one made of 1-2 cells with lumina c. $5 \mu \mathrm{m}$ in diam. and wall c. $2 \mu \mathrm{m}$ thick, the lower ones with larger, isodiametric and angular cells, 12$18 \mu \mathrm{m}$ across and wall $1.5-2.5 \mu \mathrm{m}$ thick. Photobiont layer 20-50 $\mu \mathrm{m}$ thick with algal cells c. 4-5 $\mu \mathrm{m}$ in diam. Medulla 50-120 $\mu \mathrm{m}$ thick, rather compact. Lower cortex paraplectenchymatous, $30-40 \mu \mathrm{m}$ thick, sometimes much less, with 2-4 layers of cells, $8-15 \mu \mathrm{m}$ in diam. and a c. $2 \mu \mathrm{m}$ thick wall. Lower primary tomentum formed of agglutinate bunches of 12-20 unbranched, cylindrical hyphae, free or intertwined, made of elongate cells with rather thick walls (lumina: $8-15 \times 4$ $5 \mu \mathrm{m}$; walls: 1.5-2 $\mu \mathrm{m}$ thick). Apothecia biatorine; excipulum made of radiating rows of isodiametric or rectangular cells, up to $100-120 \mu \mathrm{m}$ thick; hymenium $80-130 \mu \mathrm{m} \mathrm{high;}$ epihymenium c. $10 \mu \mathrm{m}$ thick, orange to pale brown, K-; ascospores 8/ascus, fusiform with pointed ends, straight, 24-30×7$9 \mu \mathrm{m}(n=10)$, with $1(-3)$ septa, not constricted at septa. Conidia rarely found, bacilliform, 5-7×1-1.2 $\mu \mathrm{m}$.

No substances detected by TLC.

Nomenclature and typification: Sticta canariensis was first described by Flörke (1809) on the basis of a collection made by Bory de Saint-Vincent on Tenerife. The lectotype has been chosen by Galloway (1995) and his conclusions are here confirmed. However, the species and a fortiori its epithet was not mentioned in the most famous book of Bory de Saint-Vincent (three volumes and an atlas) published in 1804 under the title "Voyage dans les quatre principales îles des mers d'Afrique" (Tenerife, Saint Helena, Mauritius, and
Reunion) (Bory de Saint-Vincent 1804; examined via Google Books, accessed on 16.1.2015). Thus, the epithet cannot be attributed to Bory de Saint-Vincent, contrarily to other epithets clearly introduced for species from Reunion and/or Mauritius and explicitly mentioned in his book, such as Cladonia candelabrum (Bory) Nyl. and Sticta ambavillaria (Bory) Ach. (respectively, as Lichen candelabrum and L. ambavillarius in Bory de Saint-Vincent 1804). The attribution of the names introduced by Flörke in 1809 on the basis of material collected by Bory de Saint-Vincent and given to him for publication has been a matter of debate in several papers: Ahti (1980) argued that these epithets must be rejected on the basis of an interpretation of the intention of Bory in making his specimens and notes available to Flörke; the sentence reads as [translated from German to English by Galloway (1995), Flörke speaking]: "He, therefore, let me have a totally free hand to name the lichens as I wished, only he wanted his diagnoses to be given alongside". Thereafter, Laundon (1984) challenged this interpretation and was followed by Galloway (1995): indeed, the epithets in Flörke's publication (1809) are not presented as synonyms, but as headings, often with descriptions. We agree with this view and further argue that if an epithet was already mentioned in Bory de Saint-Vincent (1804), it is valid under the Code of nomenclature and must be attributed to him; if not, an epithet must be attributed to Flörke, albeit on the basis of Bory's notes and collections. Therefore, the correct name for this species, which is not mentioned in Bory de Saint-Vincent (1804) is Sticta canariensis (Flörke) Delise.

Ecology: In Macaronesia, locally abundant in the laurisilva and in Erica-Myrica stands (Fayal-Brezal), especially in the most humid localities, growing on trees, mossy soils and rocks, both photomorphs can thrive together and usually not connected; in continental Europe, in the same habitats but preferably in damp, shaded and very humid niches, sometimes abundant, the cyanomorph being the most abundant form, chloromorph usually present as green lobules connected to the upper surface, or isidia masses, of the cyanomorph.

Distribution: A first map of the distribution of the cyanomorph was published by Degelius (1935: 193); since then the species has been found in SW Norway, where it is red-listed (Jørgensen and Tønsberg 2007). The species is mainly known from the western parts of Europe: United Kingdom and Ireland (Seaward 1998), France (Brittany, Western Pyrenees, Massif central: Roux et al. 2014), NW Spain and a single locality in SW Portugal (Burgaz and Martínez 2003), and Macaronesia (Canary Islands, Madeira, and the Azores). The species is very rare in the Mediterranean region, as it is known from two localities in Corsica (Roux 2013) and the Tyrrhenian coast in Italy (Nimis 1993); we have not found any recent (less than 20 years) record from the Mediterranean region. S. canariensis is also mentioned in the North America Checklist of Lichens (http://www.ndsu. edu/pubweb/ esslinge/chcklst/chcklst7.htm\#S) with a single 
reference to a collection from Ontario/Canada (Brodo 1994); this record should be re-evaluated. The distribution map available on the GBIF platform is inaccurate as it obviously includes records from other species for localities in South Africa, Central and South America (http://www.gbif.org/ species/5477265; accessed on Feb. 21, 2015).

Notes:

1. In the European and Macaronesian context, the chloromorph is unmistakable as it usually forms splendid vivid green, large thalli with almost perfectly dichotomous lobes and laminal or submarginal apothecia. The cyanomorph is easily recognized by its maculate upper surface and its abundant, marginal, and laminal phyllydia: no other species of Sticta in Europe displays those characters.

2. Within the first phylogeny of the genus provided by Moncada et al. (2014a) focusing on species from Colombia, $S$. canariensis is resolved together with other species producing a chloro- and cyanomorph, or only a cyanomorph (Moncada et al. 2013b); there are two other such clades in their study (the S. lobulata and the $S$. rhizinata clade), and our phylogenetic tree identifies a further one, including species with large and conspicuous thalli from Madagascar and the Indian Ocean, with either only a chloromorph (S. variabilis), only a cyanormorph (S. macrophylla) or both (S. dichotoma: Magain et al. 2012a). The trait of associating either with a cyanobacterium, a green alga or both is thus not constrained within the evolutionary tree of the genus and may represent opportunities of shifts in symbiosis that allow emancipation of each photomorph from the other and that drive speciation, such as in the related family Pannariaceae (Magain and Sérusiaux 2014).

3. Two haplotypes can be distinguished amongst ITS data for this species, differing by a single substitution in ITS2; both haplotypes are represented in material from the Canary Islands, whilst only one is observed in continental Europe.

Selected specimens examined: Ireland, Kerry, S of Killarney, N 52 $01^{\prime} 05^{\prime \prime} \mathrm{W} 09^{\circ} 30^{\prime} 15^{\prime \prime}, 30$ m, Feb. 2014, park with scattered trees, E. Sérusiaux s.n. (LG). France, Brittany, Cranou forest, $\mathrm{N} 48^{\circ} 18^{\prime} 55^{\prime \prime} 04^{\circ} 05^{\prime} 48^{\prime \prime} \mathrm{W}, 120 \mathrm{~m}$, Nov. 2013, mixed woodland, A. Gérault s.n. (hb Gérault, LG). Portugal, Madeira, Ribeiro Frio, N 32 $44^{\prime} 06^{\prime \prime} \mathrm{W} 16^{\circ} 53^{\prime} 11^{\prime \prime}, 900$ m, Feb. 1988, disturbed laurisilva, E. Sérusiaux 9061 (LG). Ibid., N 3244'14" W 16 53'07", 920 m, Apr. 2007, disturbed laurisilva, M. Dewald, A. Hambuckers \& E. Sérusiaux s.n. (LG). Spain, Canary Is., Tenerife, Peninsula de Anaga, N $28^{\circ} 33^{\prime} 46^{\prime \prime} \mathrm{W} 16^{\circ} 10^{\prime} 19^{\prime \prime}, 800 \mathrm{~m}$, May 2010, disturbed laurisilva, E. Sérusiaux s.n. (LG). Ibid., Punta de Anaga,

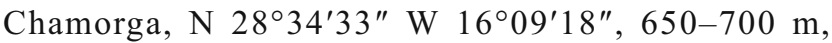

May 2013, exposed outcrops and disturbed margins of laurisilva, E. Sérusiaux s.n. (LG).

Tayl., in Mackay J.T., Flora Hibernica: 152, 1836 (Fig. 6) Mycobank \# 406124

Type: Ireland, on Hypna on the stems of trees in Akew Wood, Country of Kerry, T. Taylor (BM !, lectotype selected by Galloway, Nova Hedwigia 61: 168, 1995)

= Sticta fuliginosa f. ciliata Degel., Göteborgs Kungl. Vetenskaps- och Vitterhets-Samhälles Handlingar, Sjätte Följden, ser. B, Band 1: 19, 1941

Type: Portugal, Azores, Terceira, Serrata, På barken av ungt träd i skog, 20.4.1937, H. Persson (UPS, L-693709 !, here designated as the lectotype)

= Sticta fuliginosa auct. europ. p.p., non (Hoffm.) Ach.

Thallus first flabellate as the several lobes of a single thallus develop from a central point on a short and evanescent stipe (pseudostipe), eventually becoming suborbicular, welldeveloped thalli suborbicular to irregular, c. $1-3 \mathrm{~cm}$ in diam., rarely up to $5 \mathrm{~cm}$ in diam., rarely forming large colonies, papyraceous even when wet, and extremely brittle when dry; with $0-2$ ramifications per main lobe, branching pleurotomous to polytomous. Lobes adnate to slightly ascending, imbricate and usually overlapping each other, more isolate when growing in competition with bryophytes, slightly to distinctly revolute when mature, and wet, with rounded apices and entire to crenate, lacerate, or sinuose, not tickened margin. Upper surface smooth when young, becoming slightly, but distinctly scrobiculate to foveolate, and thus with a distinct microrelief somewhat highlighted by scars of broken isidia, greyish to dark chocolate brown, remaining of the same color when dry, but usually paler, matte, or moderately glossy, sometimes with a whitish pruina made of minute and flattened granules, giving a minutely dotted appearance under high magnification. Cilia always present on young lobes, typically abundant on fast-growing thalli in suitable conditions, lasting on parts of older thalli, especially on their regenerating parts, simple to agglutinate, with usually pointed ends, white to translucid, $0.2-0.5 \mathrm{~mm}$ long. Isidia always present, abundant, laminal, typically branched and coralloid, usually with a short $(<0.1 \mathrm{~mm})$ but distinct stipe, forming coralloid masses 0.2 $0.5 \mathrm{~mm}$ across, matte to slightly glossy, subglobose extremities forming the propagules, $25-50 \times 20-40 \mu \mathrm{m}$ and somewhat darker or bluish under high magnification. Lower surface foveolate to scrobiculate, whitish to cream-colored, darker towards the center, with sparse to dense and developed throughout primary tomentum; primary tomentum pubescent, hirsute to fasciculate, whitish to cream-colored and becoming dark brown to black towards its base. Cyphellae abundant, 15-40 per $\mathrm{cm}^{2}$, irregular to angular, rarely round, cupuliform to rarely plane, erumpent, margin indistinct or elevated and slightly involute, or rarely irregular, white to cream-colored, $0.3-1.2 \mathrm{~mm}$ in diam. with a pore $0.2-0.8(-1.0) \mathrm{mm}$ in diam. Apothecia rarely present but abundant when they are, 0.2 
Fig. 6 Sticta ciliata Tayl. a-b Fertile thalli photographed in the field in France/Brittany, photographs by Michel David and Bernard Bouffinier; see http:// www.lichensmaritimes.org/. c Lateral view of a young palmate lobe. d Upper view of young dark brown lobes, with ciliate margins and nested one in the other. $\mathbf{e}-\mathbf{f}$ Apothecia with ciliate margins. $\mathbf{g}$ Upper surface irregularly folded/ pitted with scars of broken isidia. $\mathbf{h}-\mathbf{j}$ Isidia clearly stipitate when mature. $\mathbf{k}-\mathbf{l}$ Cells of the cyphella membrane with numerous papillae on their surface. i Surface view of upper side of such cells. $\mathbf{n}$ Primary tomentum forming squarrose rhizine-like fascicles. c, d, g, h, n Azores, July 2014, E. Sérusiaux s.n., LG; e, j, k, l, m France/Brittany, Nov. 2013, A. Gérault s.n., LG; f Tenerife, Mar. 2011, P. van den Boom 45673, LG; i Tenerife, May 2015, E. Sérusiaux s.n., LG. Scale bars: c-d $2 \mathrm{~mm}, \mathbf{e}, \mathbf{f}, \mathbf{g}, \mathbf{j} 1 \mathrm{~mm}, \mathbf{h}, \mathbf{i}, \mathbf{n} 0$. $5 \mathrm{~mm}, \mathbf{k}, \mathbf{l}, \mathbf{m} 10 \mu \mathrm{m}$ (scale in $\mathrm{k}$ )
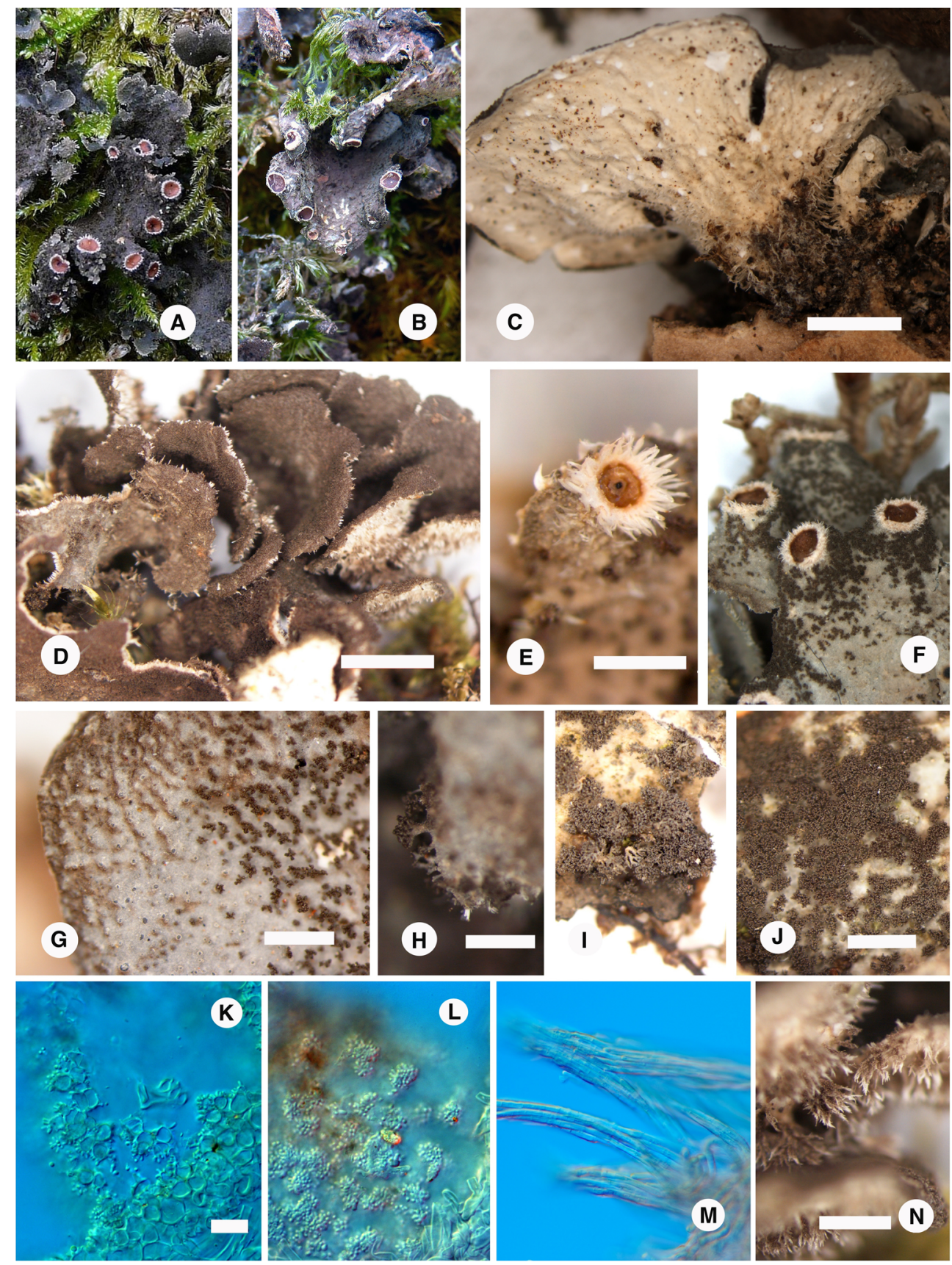

$1.2 \mathrm{~mm}$ in diam., submarginal, sessile, developed over a distinct invagination, disc reddish brown to dark brown, glossy, slightly concave especially when young, always with a crown of white to pale orange cilia. Pycnidia sometimes present, immersed in the thallus lobes, outer wall and opening without any distinct color.

Upper cortex paraplectenchymatous, 20-25 $\mu \mathrm{m}$ thick, made of 1-3 layers of rounded to isodiametric cells, c. 8$12 \mu \mathrm{m}$ in diam. with a $1-2 \mu \mathrm{m}$ thick wall. Photobiont layer 25-40(-50) $\mu \mathrm{m}$ high, with compact masses of Nostoc colonies tightly encompassed by hyphae forming rounded to angular cells, and thus designing a single layer wrapping up the
Nostoc cells. Medulla white, lax, 50-80 $\mu \mathrm{m}$ thick. Lower cortex paraplectenchymatous, $15-20 \mu \mathrm{m}$ thick, with 1-2 layers of rounded to isodiametric cells, c. $8-15 \mu \mathrm{m}$ in diam. with a 1-2 $\mu \mathrm{m}$ thick wall. Lower primary tomentum agglutinated in fascicules, with free to slightly interwined, cylindrical hyphae, with a c. $2 \mu \mathrm{m}$ thick wall. Lower secondary tomentum made of budding cells on the lower cortex surface, forming moniliform assemblages of $2-20$ cells, $5-10(-12) \mu \mathrm{m}$ in diam and with a c. $1 \mu \mathrm{m}$ thick wall. Cyphellae membrane made of a layer of rounded cells (4-8 $\mu \mathrm{m}$ in diam.) with outer side (= the side of the cyphella membrane in contact with the 
environment) covered with 6-15(-20) minute papillae, 1$2 \times 1-1.5 \mu \mathrm{m}$; these papillae tend to disintegrate in old thalli. Apothecia lecanorine, reaching $2.5-3.0 \mathrm{~mm}$ in height (measured from the lower cortex of the lobe invagination up to the epihymenium); excipulum pale orange to brownish, 50$60 \mu \mathrm{m}$ thick; hairs always present on outer parts of the excipulum, $0.2-0.3 \mathrm{~mm}$ long, formed of long and agglutinated hyphae with walls $1.5-2.0 \mu \mathrm{m}$ thick; hymenium 70-90 $\mu \mathrm{m}$ thick with epihymenium pale orange to dark orange brown, $\mathrm{K}$ -; ascospores 8/ascus, fusiform with pointed, straight or slightly curved, 26-46×7-8.5 $\mu \mathrm{m}(n=15)$, with $1(-3)$ septa, not constricted at septa, with a minute but distinct mucoid appendage on the distal end. Pycnidia without any color, producing numerous bacilliform conidia, 2-3×1-1.2 $\mu \mathrm{m}$.

No substances detected by TLC.

Nomenclature and typification:

1. Examination of the lectotype collection of $S$. ciliata in BM (Fig. 3a-c) leaves no doubt about its identity; see also http://plants.jstor.org/specimen/bm000974832?s=t. Although the epithet was reduced into synonymy with S. canariensis by Galloway (1995), the scanty collection have several characters that make it referable to the taxon here recognized as distinct from both the cyanomorph of $S$. canariensis and S. fuliginosa: indeed it has small unilobed thalli with a short stipe and a ciliate margin (Fig. 3c), a non-maculate upper surface and genuine isidia. A sentence in the original description (Mackay 1836: 152) reads as "[...] yet occasionally flat process issues suddenly from the edge, on which is borne a circular ciliate thalloid expansion, being the evolution of a bud". This could be interpreted as the description of a young apothecium with a ciliate margin; there is, however, no such structure on the type material.

2. Degelius (1941) reported Sticta fuliginosa from several islands in the Azores archipelago (Flores, São Jorge, São Miguel, and Terceira). From two localities in Terceira, he mentioned a "very peculiar form" that he had "not seen before". He further stated that "the specimens are very small, up to about $0.5 \mathrm{~cm}$ broad (young ?) and bearing in the margin rather numerous, $0.2-0.3 \mathrm{~mm}$ long, white, usually simple cilia which often form haptera at the tips. (....) Evidently, this aberrant form is genotypically settled and not produced by the environment. The specimens are numerous and the cilia occur very constantly. Neither young nor old specimens in the normal type have cilia. I shall call this ciliate form $\mathrm{f}$. ciliata". S. ciliata is a common species in the Azores archipelago where it thrives in natural habitats as well as artificial ones. Populations such as those described by Degelius (1941) occur in the Azores: they are made of small, very numerous thalli exuberantly growing on planted trees, mainly along the roads, and all thalli are bordered by tiny cilia (Fig. 3d, photograph taken on Faial island, 7. 2014, on Platanus trees at c. $530 \mathrm{~m}$ elev.). They have been carefully sampled and all belong to $S$. ciliata. Although the type collection is not designated in the original publication, a collection filed as the holotype has been found in UPS and examined via detailed photographs made available by the curators of the herbarium; the specimen is well-developed and clearly belongs to $S$. ciliata Tayl. and is here designated as the lectotype of Sticta fuliginosa f. ciliata Degel.

3. Moncada et al. (2014a) used the unpublished epithet microisidiata Magain et al. for material collected in Colombia. This epithet was used by the authors as an ad. int. name for collections from the Canary Is. and Rwanda before the epithet ciliata was re-discovered. As mentioned below, $S$. ciliata belongs to a clade yet to be distangled and occuring in the Neotropics, Hawaii archipelago (B. Moncada and R. Lücking, pers. comm.), Africa (Albertine Rift in Rwanda), Macaronesia and Western Europe.

Ecology: epiphytic on trees, usually over growing mosses, in well-preserved forests stands in France/Brittany and in Ireland/Kerry; also found over saxicolous mosses in the same localities in France/Brittany; in Macaronesia, on trees and mossy rocks within the laurisilva and in Erica-Myrica stands (Fayal-Brezal), especially in the most humid localities.

Distribution: currently known from France/Brittany and Ireland/Kerry, but expected to occur elsewhere in suitable localities in Western Europe, such as Scotland and the Western Pyrenees; in Macaronesia, known from Tenerife, Gomera and La Palma in the Canary Islands, Pico and Faial in the Azores and expected to occur in Madeira as well. Material from Colombia and Rwanda are resolved within the clade, and are thus tentatively considered as $S$. ciliata.

Notes:

1. Fresh material of that species can be easily recognized by its delicate and most usually ciliate thallus margin, especially for young thalli, and abundant tiny papillae over the cells of the cyphellae membrane. However, great care is required as regeneration lobules of all other isidiate species can have marginal cilia, albeit very rarely, and our observations of papillae on the cells of the cyphellae membrane are conclusive only for fresh and wellpreserved material.

In a European context, the only other species that produces papillae on the cells of the cyphellae membrane is $S$. fuliginoides sp. nov., easily characterized by its nonciliate thallus margin and a mushroom-like form for single lobes thalli at early stages of development; further $S$. fuliginoides sp. nov. never produces apothecia. Although apothecia are known in the type material of S. fuliginosa and putatively from a recent collection from France/Brittany (see under that name for further 
comments), apothecia with ciliate margins are restricted to $S$. ciliata in the material examined for this study. Fertile specimens have been found in France/Brittany, the Canary Is. and the Azores.

2. Within the first phylogeny of the genus provided by Moncada et al. (2014a) focusing on species from Colombia, $S$. ciliata is resolved within the $S$. fuliginosa clade, and more precisely to the $S$. gyalocarpa subclade; material of $S$. microisidiata from Colombia is resolved in it; this subclade comprises several rather well-known species such as $S$. hirta (Nyl.) Trev. and S. gyalocarpa (Nyl.) Trevis. and recently described ones such as $S$. arbuscula Moncada and Lücking (2012). Quite interestingly, the latter species also has numerous tiny papillae on cells of the cyphellae membrane.

The sequences of $S$. ciliata produced for this study with four loci (ITS, LSU, mtSSU and RPBI) are very distinctive; nevertheless, our phylogenetic analyses show clear affinities with $S$. fuliginoides sp. nov., the only other species with papillae on cells of the cyphellae membrane included in this study. As mentioned under S. fuliginosa, the material referred to that epithet by Moncada et al. (2014a) actually belongs to $S$. fuliginoides sp. nov.; therefore, the clade named $S$. fuliginosa in their study does not include the eponym species.

3. A surprizing and unexpected variation is detected within this species, and further, the 4-loci phylogenetic tree (Fig. 2) does not resolve it identically as the TCS haplotype network (Fig. 3). As a matter of fact, the phylogenetic tree resolves two lineages with rather long branches, but weak support: one includes two accessions from the Canary Islands, and the other one includes accessions from continental Europe, Macaronesia (Canary Is. and the Azores), Rwanda, and Colombia. The latter clade is divided into two: one accession from France/Brittany is sister to all others, with strong support when both accessions from Colombia are excluded. Indeed, these two accessions contribute weakly to that branch as they are represented by ITS data only.

Interestingly, the TCS haplotype network (Fig. 2) yields another story about the relationships between haplotypes within that species. Here, ITS sequences from 29 accessions are included and the algorithm used for the construction of the haplotype network does not exclude any region: the whole variation within ITS sequences is considered. The accession from Rwanda is excluded from the network under the $90 \%$ limit constraint; eight haplotypes occur in continental Europe and Macaronesia whilst both accessions from Colombia are included in the network but clearly distinguished from those from continental Europe and Macaronesia. Three haplotype groups can be easily distinguished: (1) one with the single accession from Ireland, and thus assumed to represent the type population, further comprising material from France/ Brittany and the Azores; (2) a second one differing by eight mutational steps and present in the same geographical area plus the Canary Islands (Tenerife and La Palma); and (3) a third one also differing by eight mutational steps from the typical one, and represented by a single accession from Tenerife in the Canary Islands. The pattern is thus very different as the two main lineages found in the 4-loci phylogenetic tree are not recovered: the most distinct ITS haplotype (\#3) represented by a single accession from Tenerife is included in the first lineage whilst its sister accession in the 4-loci phylogenetic tree is resolved in a different haplotype group (\#2) in the TCS construction. Examination of the positions in ITS1 and ITS2 that support the haplotype network show that they are excluded in the 4-loci phylogenetic analysis as they belong to most variable and thus ambiguous regions in the data maxtrix.

In any case, no morphological, nor anatomical diagnostic characters could be detected to distinguish the two main lineages of the 4-loci phylogenetic tree, nor for the three main haplotypes observed in the TCS network. More work is thus needed to further assess the variation encountered. We therefore consider the variation in continental Europe and Macaronesia to be infraspecific. Populations discovered in Rwanda and in Colombia may represent two further species.

4. A short sequence (15-16 bp) in ITS2 should allow identification of the three main haplotypes within $S$. ciliata in continental Europe and Macaronesia, the diagnostic positions are underlined:
(1) Type

\section{CCTCGTGCCATCGTAI}

\section{CETCGC CTATCGTA} ICTCGC CTATCGTA므
Selected specimens examined:

Ireland, Kerry, S of Killarney, N 52 $01^{\prime} 05^{\prime \prime} \mathrm{W} 09^{\circ} 30^{\prime} 15^{\prime \prime}$, 30 m, Feb. 2014, Quercus forest, E. Sérusiaux s.n. (LG). France, Brittany, Hopital Camfrout, N 48 $19^{\prime} 59^{\prime \prime}$ W 04 $01^{\prime}$ 22", 15 m, Nov. 2013, disturbed forest, A. Gérault s.n. (hb Gérault, LG). Portugal, Azores, Pico Is., 2011, P. K. Divakar

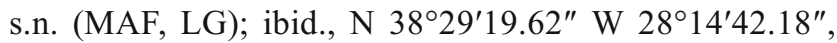
240 m, July 2014, plantations of Pinus with fragments of natural vegetation, E. Sérusiaux s.n. (LG); ibid., Faial Is., N $38^{\circ} 35^{\prime} 56.75^{\prime \prime} \mathrm{W} 28^{\circ} 40^{\prime} 53.85^{\prime \prime}, 530 \mathrm{~m}$, July 2014, on Platanus by the road, E. Sérusiaux s.n. (LG). Spain, Canary Is., Tenerife, Las Montanas de Anaga, N 28 $8^{\circ} 33.53^{\prime} \mathrm{W}$ 160.19", Mar. 2011, 775 m, laurisilva, P. van den Boom 45673 (hb. van den Boom); ibid., N 28 34'22" W 1609'55", 690 m, May 2014, laurisilva, E. Sérusiaux s.n. (LG); ibid., La 


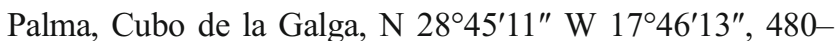
500 m, May 2013, disturbed laurisilva, E. Sérusiaux s.n. (LG).

Sticta fuliginoides Magain \& Sérus., sp. nov. (Fig. 7)

Mycobank \# 813824

Species of Sticta distinguished from other isidiate species in Western Europe with a thallus lichenized with a cyanobacterium by its thallus developing as a single lobe vase- or trumpet-like, with typically revolute margins, and cells of the cyphella membrane covered with papillae.

= Sticta fuliginosa auct. p.p., non (Hoffm.) Ach.

Type: Spain, Canary Is., Gomera, Parque Nacional de Garajonay, SW of the summit (Alto de Garajonay), N $28^{\circ} 05^{\prime}$ 52" W 017 14'49", 1240 m, May 2012, degraded laurisilva, E. Sérusiaux LG DNA 3012 (LG-holotypus; TFC - isotypus).

Thallus first developed on a short, but robust stipe (up to $1 \mathrm{~cm}$ high) as a single lobe vase- or trumpet-shaped, typically with revolute margins, and thus looking like a young agaric mushroom, either in humid or dry conditions; eventually developing several flabellate lobes with an irregular or mostly suborbicular outline, usually $2-3 \mathrm{~cm}$ in diam., up to $5 \mathrm{~cm}$ in suitable conditions, rarely larger; several thalli growing together may mimic large thalli, subcoriaceous but rather brittle when dry. Lobes with no or 1-2 branching, adnate to ascending, especially when young, imbricate and overlapping each other, plane to slightly involute with rounded to obtuse or even truncate lobes (especially in old thalli) that typically have a strongly revolute entire margin, old thalli can have a crenate to lacerate and hardly revolute margin. Upper surface smooth to slightly scrobiculate, especially in old lobes on which scars of broken isidia can mimic macules, dark brown or rarely pale greyish, in wet or dry conditions, matte or slightly glossy. Cilia most usually absent, sometimes seen on small regenerating lobes, simple, white, $<0.5 \mathrm{~mm}$ long. Isidia always present, abundant, laminal, dispersed throughout, first simple and globose or with a flattened top, eventually forming upright coralloid masses, $<0.2 \mathrm{~mm}$ high, sometimes forming substipitate lobules on old thalli, of the same color as the thallus or darker, matte to slightly glossy. Lower surface smooth or costillate to scrobiculate, sometimes strongly, pale orange to brownish, darker towards the center on old thalli, with sparse to dense and developed throughout primary tomentum, absent in some thalli; primary tomentum pubescent
Fig. 7 Sticta fuliginoides Magain $\&$ Sérus., sp. nov. a Large population of well-developed thalli on tree (photograph taken in the field, Feb. 2014, Ireland/ Kerry). b-c Upper and lower view of a young vase-like thallus, showing the lower reticulate surface, typically revolute margin and stipe covered with primary tomentum. c Upper surface with isidia. d Lower primary tomentum. e-f Cells of the cyphella membrane with several papillae on their upper surface. bg Type collection (La Gomera, May 2012, E. Sérusiaux s.n., LG). Scale bars: b, c $2 \mathrm{~mm}$ (scale in b), d $1 \mathrm{~mm}, \mathbf{e} 0.5 \mathrm{~mm}, \mathbf{f}, \mathbf{g} 10 \mu \mathrm{m}$ (scale in $\mathrm{f}$ )
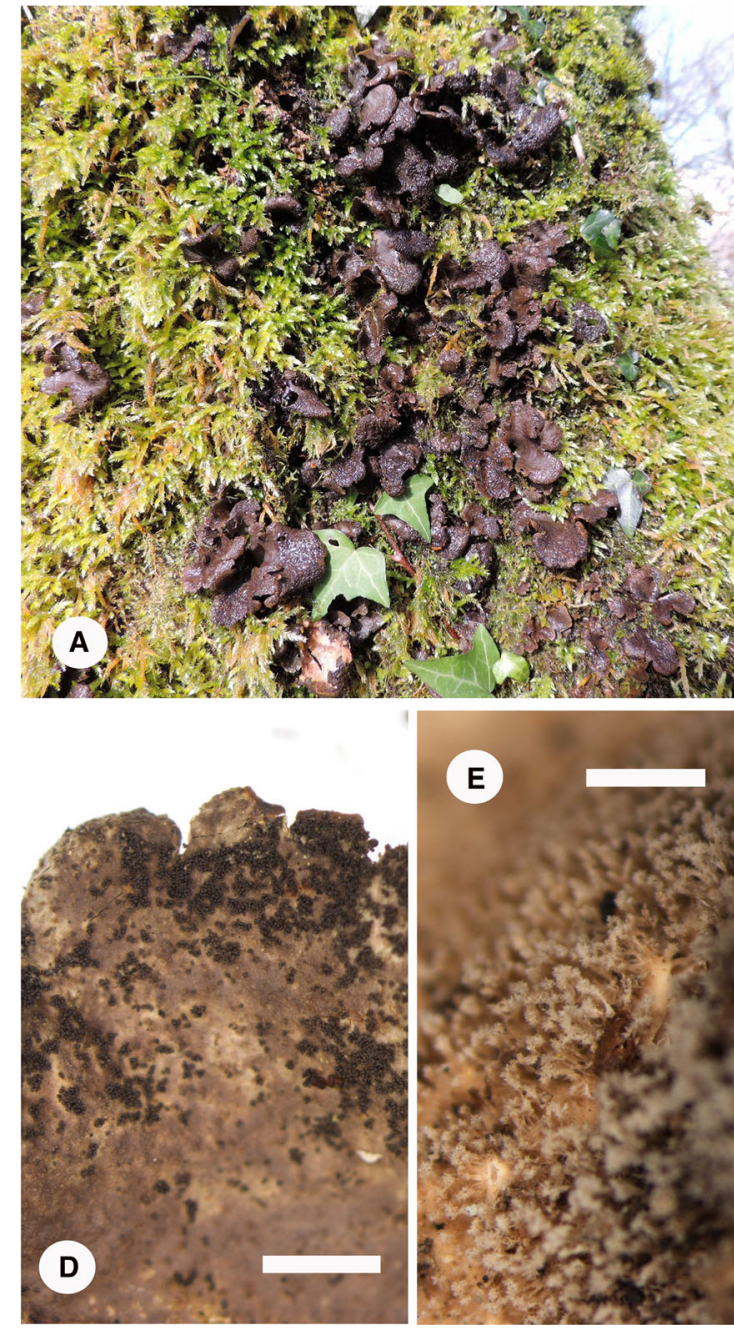
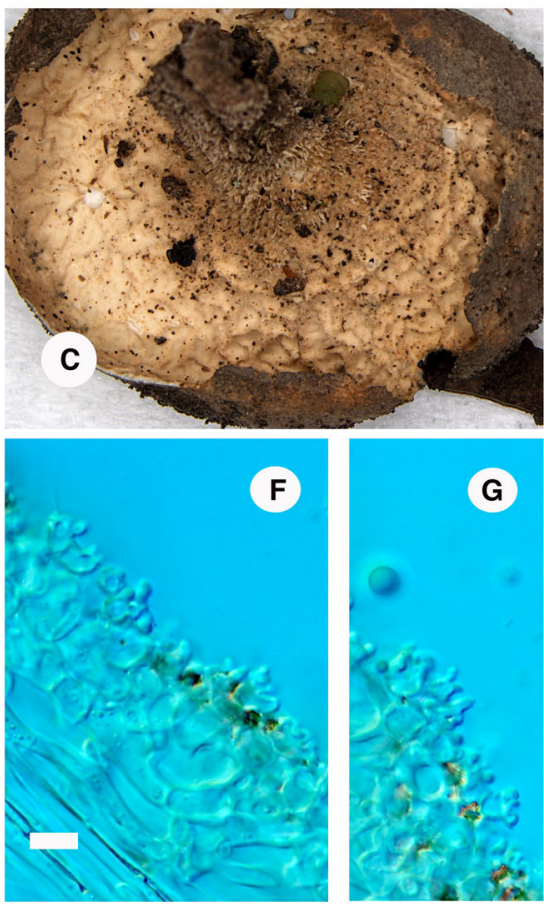
to hirsute, or fasciculate, especially towards the center, whitish to dark brown towards the center. Cyphellae usually abundant, rarely sparse, 20-30 per $\mathrm{cm}^{2}$, round or angular, urceolate with a wide pore, erumpent to prominent, margin elevated and involute, whitish to cream-colored, rarely brownish, 0.4$0.6 \mathrm{~mm}$ in diam., larger ones on old thalli can reach $1.5 \mathrm{~mm}$ in diam. Apothecia and pycnidia never produced.

Upper cortex paraplectenchymatous, 25-40 $\mu \mathrm{m}$ thick, usually differentiated in two layers, the upper one made of a single row of elongate to rounded cells, $5-7 \times 3-4 \mu \mathrm{m}$ with a c. $1 \mu \mathrm{m}$ thick wall and the other one made of 3-5 layers of rounded to isodiametric cells, $8-12 \mu \mathrm{m}$ in diam. with a $1.5 \mu \mathrm{m}$ thick wall. Photobiont layer 20-30 $\mu \mathrm{m}$ thick with compact masses of Nostoc encompassed by hyphae forming rounded to angular cells and thus designing a single layer wrapping up the Nostoc cells. Medulla white, lax, 40-60 $\mu \mathrm{m}$ high. Lower cortex paraplectenchymatous, 30-40 $\mu \mathrm{m}$ thick, made of 3-5 rows of isodiametric cells, up to 20-22 $\mu \mathrm{m}$ across in the stipe, with a 2$3 \mu \mathrm{m}$ thick wall. Lower primary tomentum agglutinated in fascicles, with more than 20 unbranched or slightly branched, flexuose hyphae that are either free or more frequently intertwined, with a c. $1.5 \mu \mathrm{m}$ thick wall. Lower secondary tomentum always present albeit it can be hardly detected under high magnification, made of free, unbranched moniform hyphae, $<20 \mu \mathrm{m}$ long, with $1 \mu \mathrm{m}$ thick wall, with budding apices, producing individual rounded cells, $6-8 \mu \mathrm{m}$ in diam., acting as diaspores. Cyphellae membrane made of a layer of rounded cells (5-9 $\mu \mathrm{m}$ in diam.) with outer side (= the side of the cyphella membrane in contact with the environment) covered with 4-6(-8) minute papillae, $1-2.5 \times 1-1.5 \mu \mathrm{m}$; these papillae tend to disappear in old thalli; detached cells of the membrane seem to produce up to 15-20 papillae per cell.

No substances detected by TLC.

Etymology: the epithet of this new species was chosen to evoke the confusion that has prevailed for two centuries in the perception of the taxonomic variation in isidiate species of Sticta in Europe.

Ecology: on mossy trees and rocks within forests or at their edges, incl. parkland conditions in oceanic climate, found at the montane zone (Fagus sylvatica and Abies alba mixed forest) at c. $1000 \mathrm{~m}$ elev. down to Quercus-dominated forest at sea level; in Macaronesia, on trees and mossy rocks within the laurisilva and in Erica-Myrica stands (Fayal-Brezal), especially in the most humid localities.

Distribution: as this species has been confused with $S$. ciliata and $S$. fuliginosa for two centuries, its distribution might be underestimated. ITS data confirm it occurs in continental Europe, the Canary Islands, eastern North America, and Colombia.

Notes:

1. Sticta fuliginoides sp. nov. can be distinguished in its early stages of development by its single lobe thalli vase- or trumpet-like, with typically revolute margins. The latter character is maintained when thalli are more developed and branched and have thus lost their vase- or trumpetlike shape. Mature thalli remain rather small (less than $5 \mathrm{~cm}$ in diam) and this character, associated with the revolute margin, provide good diagnostic evidence for the distinction from $S$. fuliginosa. Papillae are present on the cells of the membrane of cyphellae and, at least in fresh or recently collected material, provide a further character to distinguish it from $S$. fuliginosa. S. ciliata also produces such papillae, usually much more abundant than in S. fuliginoides, but most usually has a ciliate margin and produces apothecia in suitable localities, whereas $S$. atlantica has an upper surface with typically regular or irregular swellings or ridges on which isidia start their development to form coralloid stipitate masses.

2. Within the first phylogeny of the genus provided by Moncada et al. (2014a) focusing on species from Colombia, $S$. fuliginoides sp. nov. is assigned to the $S$. fuliginosa clade, that comprises three subclades, the first one with only $S$. fuliginoides sp. nov. Indeed, all accessions included as $S$. fuliginosa in Moncada et al. (2014a) represent this species. The other two subclades comprises no less than 20 species, incl. S. ciliata (as microisidiata, see under S. ciliata).

3. Five haplotypes can be distinguished within the ITS data: they differ from each other by one or two indels in ITS1 and one or two indels plus one substitution in ITS2. The haplotype network indeed demonstrates that they are closely related (Fig. 2). Interestingly the accessions from the USA/North Carolina (accessions AY173387-9, as S. fuliginosa: McDonald et al. 2003) belong to two haplotypes while all accessions from the Canary Islands (Gomera and La Palma, where the species is rather common) belong to a single haplotype. The two accessions from the U.K./Wales (accessions KC011069 and KC732454, as S. fuliginosa: Moncada et al. 2014a) form a unique haplotype. The single accession from Colombia (KC732709, as S. fuliginosa: Moncada et al. 2014a) is unique and differs from the closest haplotype by one indel in ITS1 and three indels in ITS2. Although this variation should be evaluated with more loci within a phylogenetic framework, we consider for the time being that all these accessions can be referred to as $S$. fuliginoides.

Selected specimens examined:

Ireland, Kerry, S of Killarney, N 52 $01^{\prime} 05^{\prime \prime} \mathrm{W} 09^{\circ} 30^{\prime} 15^{\prime \prime}$, 30 m, Feb. 2014, Quercus forest, E. Sérusiaux s.n. (LG). France, Brittany, Huelgoat, N 48 22'03" W 0344'06", Nov. 2013, mossy outcrop in mixed forest, F. Séité s.n. (LG, herb. Séité). Ibid., Dept. Haut-Rhin, Hohneck, N $48^{\circ} 02^{\prime} \mathrm{E}$ $07^{\circ} 01^{\prime}$, c. $1000 \mathrm{~m}$ elev, open mixed forest, June 2010, E. Sérusiaux s.n. (LG). United Kingdom, Devon, Popham 


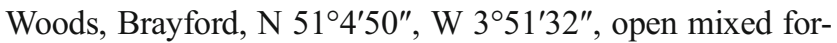
est, Jan. 2014, N. Magain s.n. (LG).

Sticta fuliginosa (Hoffm.) Ach. Methodus Lichenum, p. 280, 1803. (Fig. 8)

Mycobank \# 122533

Bas.: Lobaria fuliginosa Hoffm., Deutschland Flora, vol. 2, p. 109, 1796.

Type: United Kingdom, Wales, Cader Idris; Icon. In Dillenius, Historia Muscorum, tabl. 26, Fig. 100A, 1742 (lectotype designated by Laundon, Lichenologist 16: 218-219, 1984); corresponding specimen in herb. Dillenius (OXF !, epitype, designated by Jørgensen and Tønsberg, Nordic Lichen Flora 3: 146, 2007).

Thallus first developing as a bunch of several palmate, elongate or flabellate lobes, but without any distinct stipe, eventually developing typically (sub-)orbicular and overlapping lobes, usually reaching 5-7 cm in diam in Europe, much larger (up to 10-12 cm across) in tropical areas, rather fragile and papyraceous, rather brittle when dry. Lobes with 0-2 branching, adnate or ascending, especially when well-developed, overlapping each other, branching polytomous or irregular, most usually (sub-) orbicular, rarely irregular to ligulate, dissected in old thalli, apices plane and slightly undulating, sometimes slightly revolute, margin entire to crenate or even lacerate. Upper surface smooth to more usually scrobiculate to faveolate, undulating, greyish to brown in wet or dry conditions, maculae and cilia most usually absent; maculae irregularly developed, only seen in European material. Isidia always present, abundant, laminal, dispersed throughout, mainly developing on ridges of the upper surface (margins of the shallows depressions on the upper surface) first simple, glossy and rounded to applanate, but soon developing vertical coralloid masses, sometimes substipitate, up to $0.5 \mathrm{~mm}$ in height, darker than the thallus. Lower surface costillate to scrobiculate, sometimes strongly, white or pale orange to brownish, darker towards the center on old thalli, with sparse (especially in European material) to dense and developed throughout primary tomentum, absent in some thalli; primary tomentum pubescent to hirsute, especially towards the center, whitish to dark brown towards the the center. Cyphellae abundant, 20-40 per $\mathrm{cm}^{2}$ but more abundant (up to $45-60$ per $\mathrm{cm}^{2}$ towards the margins), round or angular,
Fig. 8 Sticta fuliginosa (Hoffm.) Ach. a Large specimen wrapping up a small tree in Madagascar (photograph taken in the field, Oct. 2014, E. Sérusiaux). b typical thalli on trunk of Alnus in Ireland/Kerry (photograph taken in the field, Feb.2014,

E. Sérusiaux). c-d Upper surface with developement of isidia (Rwanda, Sep.2010, E. Sérusiaux s.n., LG). e, h Lower surface with primary tomentum welldeveloped (e Azores, July 2014, E. Sérusiaux s.n., LG) or poorly developed (h Ireland/Kerry, Feb. 2014, E. Sérusiaux s.n., LG). $\mathbf{h}, \mathbf{i}$ Conidiogenous cells and conidia all along the fascicles (Madagascar, Oct. 2008, E. Sérusiaux s.n., LG). g Photograph produced by François Séité (group http://www. lichensmaritimes.org/) of a lobe of Sticta fuliginosa with apothecia, representing the only recent reliable data on apothecia production by this species. Scale bars: c, d, e, h $1 \mathrm{~mm}$ (no scale shown in e), f, i $10 \mu \mathrm{m}$ (scale in $\mathrm{f}$ )
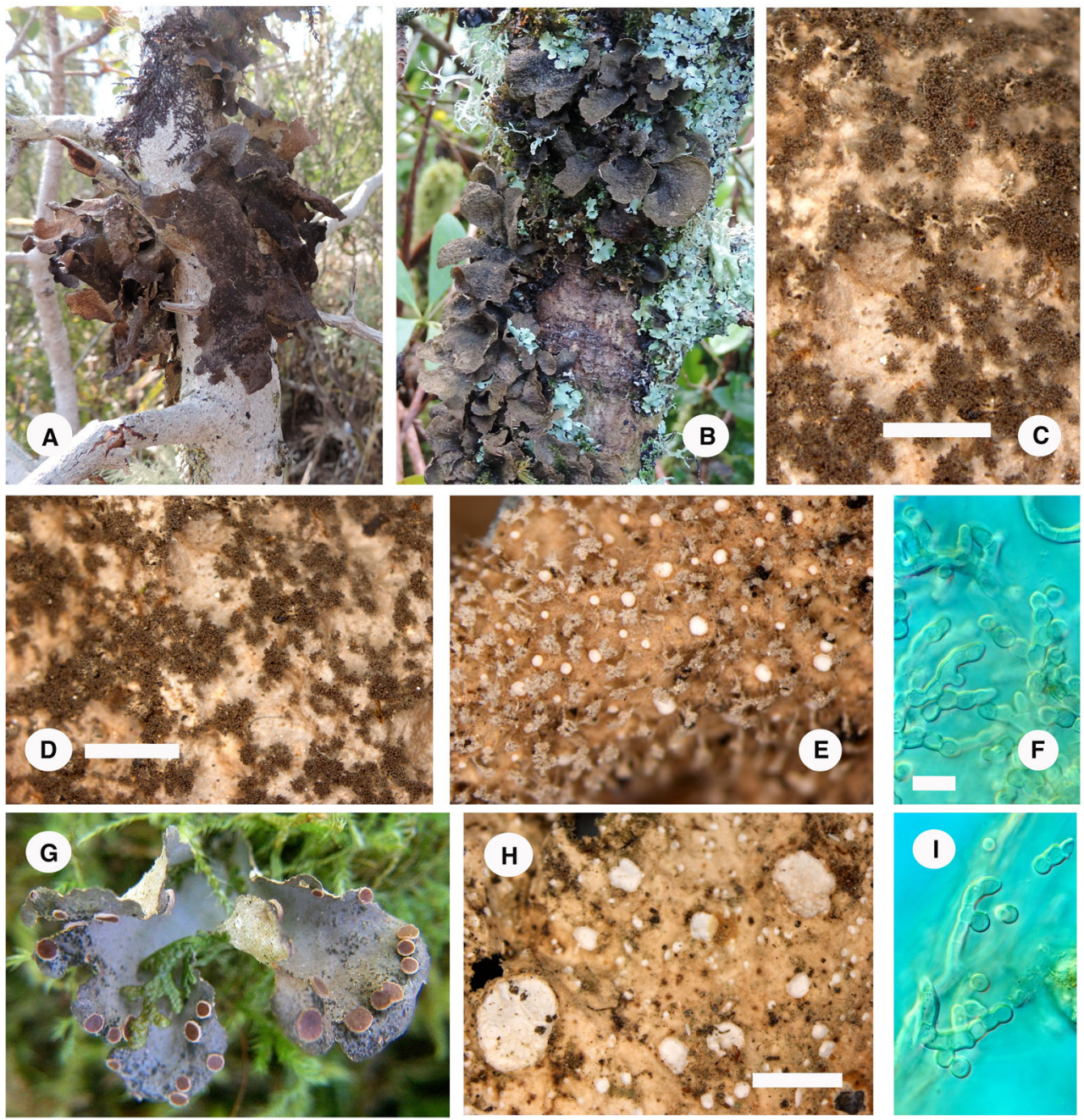
cupuliform to urceolate with a wide pore, prominent to suprasessile, margin erect, slightly revolute, whitish to cream-colored, or brownish, $0.4-1.1 \mathrm{~mm}$ in diam., larger ones are more angular and can reach 1.5-2.1 mm (cyphellae up to $3.0 \mathrm{~mm}$ in diam. seen in material from the Azores). Apothecia and pycnidia never seen in the material examined; one picture recently made in France/Brittany (Fig. 8g) most probably represents a thallus of this species with apothecia; otherwise apothecia only known from the type material (Fig. 3f): 1.5$2.5 \mathrm{~mm}$ in diam., disc pale orange brown, flat, with a raised, paler, hairy margin (hairs small, pale to translucid, fluffy and not stiff); hymenium and ascospores not examined.

Upper cortex paraplectenchymatous, 30-40 $\mu \mathrm{m}$ thick, usually not differentiated in two layers, although the upper cells are usually smaller and more applanate than the others, 5$12 \mu \mathrm{m}$ in diam. and with a c. $2 \mu \mathrm{m}$ thick wall. Photobiont layer 45-55 $\mu \mathrm{m}$ thick with compact masses of Nostoc encompassed by hyphae forming rounded to angular cells. Medulla white, lax to compact, $60-80 \mu \mathrm{m}$ high. Lower cortex paraplectenchymatous, $45-50 \mu \mathrm{m}$ thick, made of 3-4 rows of isodiametric cells, $8-14 \mu \mathrm{m}$ in diam. and with a $2-2.5 \mu \mathrm{m}$ thick wall. Lower primary tomentum agglutinated in fascicles, with more than 20 unbranched, cylindrical, free or sometimes intertwined hyphae, with cells $15-22 \times 5-6 \mu \mathrm{m}$ and with a c. $1.5 \mu \mathrm{m}$ thick wall; hyphae budding along their length or their extremities, and producing isolated cells acting as conidia, either rounded or slightly ellipsoid, 4-6 $4 \mathrm{~m}$, incl. a c. $1 \mu \mathrm{m}$ thick wall. Lower secondary tomentum not seen. Cyphellae membrane with outer cells never producing papillae.

No substances detected by TLC.

Nomenclature and typification: the epitype specimen was designated by Jørgensen and Tønsberg (Nordic Lichen Flora 3: 146, 2007) and can be examined online at the Oxford Herbarium web site (http://herbaria.plants.ox.ac.uk/bol/ MUSCORUM/image/HM-sheet_072.jpg/Zoom?width= $760 \mathrm{px} \&$ height $=760 \mathrm{px}$ ). This specimen has been examined (Fig. 2) and corresponds to one of the four species now recognized within isidiate populations of Sticta in Western Europe (Jørgensen and Tønsberg 2007; Smith et al. 2009; Wirth et al. 2013). Further, we could produce ITS sequences for fresh material corresponding to that species in all sampled localities (France/Brittany and Vosges, U.K./Devon and Somerset and Ireland/Kerry). They are all strictly identical: we thus consider that they represent $S$. fuliginosa. The type material features a thallus with abundant apothecia; apothecia have not been found in any collections assembled for this study; a picture recently made by F. Séité in France/Brittany (Fig. $8 \mathrm{~g}$ ) most probably represents a thallus of this species with apothecia but unfortunately the population was not sampled.

Ecology: on mossy trees and rarely on rocks within forests or at their edges, incl. parkland conditions, locally common but surprisingly rare in France/Brittany, and interestingly not found in the Vosges; in Macaronesia, on trees and mossy rocks within the laurisilva and in Erica-Myrica stands (FayalBrezal), especially in localities with frequent mist.

Distribution: Our molecular data support the presence of this species in France/Brittany, U.K./Devon and Ireland/Kerry as well as in the Canary Islands (Gomera), the Azores archipelago (Pico Is.), Reunion, Madagascar, Rwanda (Fig. 154, as S. fuliginosa in Macrolichens of East Africa by Swinscow and Krog 1988 actually represents this species) and South Africa; accessions retrieved from GenBank further support its presence in the eastern USA (as $S$. sylvatica in Hodkinson et al. 2014), Japan and New Zealand. S. fuliginosa could thus be a widespread species in both hemispheres.

Notes:

1. This species can be distinguished by its rather large (up to 5-7 cm in diam.), suborbicular and slightly ascending thalli, with a plane, undulating margin, rarely revolute; it might be confused with $S$. fuliginoides sp. nov., which can be recognized by its typically revolute lobe margin, especially in young thalli, and presence of papillae on cells of the cyphella membrane. The distinction with S. ciliata is usually easy as this species has a very delicate, usually much smaller thalli with a ciliate margin, whilst S. atlantica has distinct, albeit irregular, swellings over its thallus surface.

2. Sticta fuliginosa, as circumscribed here, is not included in the first phylogeny of the genus provided by Moncada et al. (2014a) focusing on species from Colombia; indeed, all accessions represent $S$. fuliginoides sp. nov. (see under that species). Therefore and quite unfortunately the socalled $S$. fuliginosa clade does not include this species. $S$. fuliginosa is resolved into the $S$. humboldtii clade, together with the eponym species, S. limbata and other undescribed species.

3. Only two haplotypes (based on ITS) can be recognized in the many collections available to us from continental Europe, Macaronesia and Africa and they show a clear distribution partition (Fig. 2): haplotype (1) was detected in material from France/Brittany, U.K./Devon and Somerset, Ireland, the Canary Islands and the Azores; haplotype (2) differs from the former by a single substitution in ITS2, and is not sympatric with haplotype (1) as it has been detected in USA/North Carolina (JX064536, as S. sylvatica: Hodkinson et al. 2014), Rwanda, South Africa, Madagascar, Reunion, Japan (AB239345: Takahashi et al. 2006), and New Zealand (AF350310: Thomas et al. 2002).

Quite interestingly haplotype (2) differs from the main haplotype of the sorediate taxon S. limbata by a single substitution in ITS1, and moreover a single accession of S. limbata from Western North America (AY173391: McDonald et al. 2003) has the same haplotype as (2) of 
S. fuliginosa. Although we could not locate this specimen at MIN, we have no reason to believe that the identification was wrong: McDonald et al. (2003) would not have named this specimen $S$. limbata if soredia were absent and isidia present. It is the only exception to the use of the ITS barcode for the distinction of these two widely used epithets for two species of Sticta in the northern hemisphere.

Two accessions from U.K./Wales (accessions KC011069 and KC732454, as S. fuliginosa: Moncada et al. 2014) are strictly identical with $S$. fuliginoides sp. nov., haplotype (1), as well as one accession from USA/ North Carolina (accession AY173387, as S. fuliginosa: McDonald et al. 2003).

The barcode ITS sequence can thus be used to distinguish $S$. fuliginosa from $S$. limbata with one exception. The 4-loci phylogenetic tree, however, does not resolve both species (identified with the single diagnostic character of isidia versus soredia) as single entities, providing a nice example of incomplete lineage sorting for a recent divergence.

4. An accession (AY124095) from China named S. fuliginosa (Lohtander et al. 2002) is almost identical with a collection from British Columbia (Canada) identified as $S$. cfr. sylvatica by its collector (T. Goward, \# 2009-246) and other unnamed collections from the Canary Islands. So far, no validly published epithet has been found for this species which will be examined in another forthcoming paper. It is referred as sp. 1 in the phylogenetic tree (Fig. 1). Another accession represents a further different species as its ITS diverges significantly from $S$. fuliginosa as well as from all other species dealt with in this paper: DQ419943 from Canada/British Columbia (Cornejo et al. 2009).

Selected specimens examined:

Ireland, Kerry, S of Killarney, N 52 $01^{\prime} 05^{\prime \prime}$ W $09^{\circ} 30^{\prime} 15^{\prime \prime}$, 30 m, Feb. 2014, Quercus forest, E. Sérusiaux s.n. (LG). France, Brittany, Trégarvan, N 48 $15^{\prime} 08^{\prime \prime} \mathrm{W} 04^{\circ} 13^{\prime} 24^{\prime \prime}$, 20 m, Nov. 2013, mixed swamp forest, B. Bouffinier s.n. (LG, herb. Bouffinier). Madagascar, Angavokely Forest

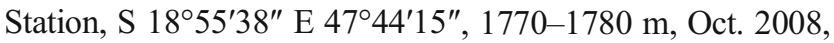
degraded ericaceous shrub, 10.2008, E. Sérusiaux s.n.; ibid., 10.2014, E. Sérusiaux s.n. (LG). Portugal, Azores, Pico Is., 2011, P. Divakar s.n. (LG). Reunion, Bebour forest, $21^{\circ} 7^{\prime} 41^{\prime \prime}$ S 55 $34^{\prime} 55^{\prime \prime} \mathrm{E}, 1370-1380 \mathrm{~m}$, mixed montane forest, Nov. 2009, N. Magain \& E. Sérusiaux s.n. (LG). Rwanda, Nyungwe National Park, Rwasenkoko, S 02 31'29" E 029 20'26", 2300-2350 m, Sept. 2010, Erica thickets, E. Sérusiaux s.n. (LG). South Africa, Western Cape Province, S $33^{\circ} 59.14^{\prime} 20^{\circ} 49.39^{\prime} \mathrm{E}, 447 \mathrm{~m}$, Oct. 2010, afromontane forest, B. Goffinet 10242 (UCONN). Spain, Canary Is., Gomera,

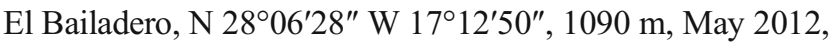
Fayal-Brezal tickets, E. Sérusiaux s.n. (LG). United
Kingdom, Devon, Sampford Spiney, N 50³2'3', W 43' 37", on mossy stone walls, Jan. 2014, N. Magain s.n. (LG)

Sticta limbata (Sm.) Ach. Meth. Lich.: 280, 1803. (Fig. 9)

Lichen limbatus Sm. \& Sowerby, in Smith J. E. and Sowerby J., English botany 16: 1104, 1803.

Mycobank \# 406275

Type: United Kingdom, Wales, Haford, Cardiganshire, J. E. Smith (BM-lectotype !; designated by Galloway D., Lichenologist 26: 259, 1994).

Thallus usually developing as a bunch of several palmate, elongate or flabellate lobes, without any distinct stipe, eventually developing typically (sub-)orbicular and overlapping lobes, c. $1-3 \mathrm{~cm}$ in diam., rarely larger, even in suitable conditions, fragile and papyraceous, rather brittle when dry. Lobes with $0-1(-2)$ branching, adnate or ascending, especially when well-developed, overlapping each other, branching polytomous or irregular, most usually (sub-) orbicular, rarely irregular to ligulate, apices slightly undulating, plane or usually slightly revolute, margin entire to crenate and sinuose, and entirely covered with soralia forming a somewhat swollen edge. Upper surface smooth, plane or undulating, pale to dark brown or greyish in wet or dry conditions, faintly maculate when greyish, matte or slightly glossy, cilia absent. Soralia always present, erupting from the medulla just underneath the upper cortex, on the upper surface, mostly towards the margins or on the lobe margins, typically first forming a star-like structure with its center slightly convex and made of immature soredia, bordered by small, pale to whitish triangular lobes, made of the dissected and disrupted upper cortex; those starlike soralia eventually developing in large, coalescent masses, invading the thallus surface and especially the margins along most of their lengths; scars of the upper cortex mostly persistent at the edges of the extensive soralia, or within them; soredia rather coarse to farinose, typically bluish grey, rarely brownish. Lower surface costillate to scrobiculate, white or pale orange to brownish, rarely darker towards the center on old thalli, with sparse to dense and developed throughout primary tomentum, absent in some thalli; primary tomentum pubescent to hirsute, especially towards the center, whitish, rarely dark brown towards the center. Cyphellae abundant, 20-40 per $\mathrm{cm}^{2}$, but slightly more abundant towards the margins, round or angular, cupuliform to urceolate with a wide pore, prominent to suprasessile, margin erect, slightly revolute, whitish to cream-colored, or brownish, $0.3-1.0 \mathrm{~mm}$ in diam. Apothecia and pycnidia never produced.

Upper cortex paraplectenchymatous, 30-40 $\mu \mathrm{m}$ thick, not differentiated in two layers, although the upper cells are usually smaller and more applanate than the others, $5-12 \mu \mathrm{m}$ in diam. and with a c. $2 \mu \mathrm{m}$ thick wall. Photobiont layer 35 $50 \mu \mathrm{m}$ thick with compact masses of Nostoc encompassed by hyphae forming rounded to angular cells. Medulla white, lax to compact, 65-75 $\mu \mathrm{m}$ high. Lower cortex paraplectenchymatous, $45-50 \mu \mathrm{m}$ thick, made of 3-4 rows 

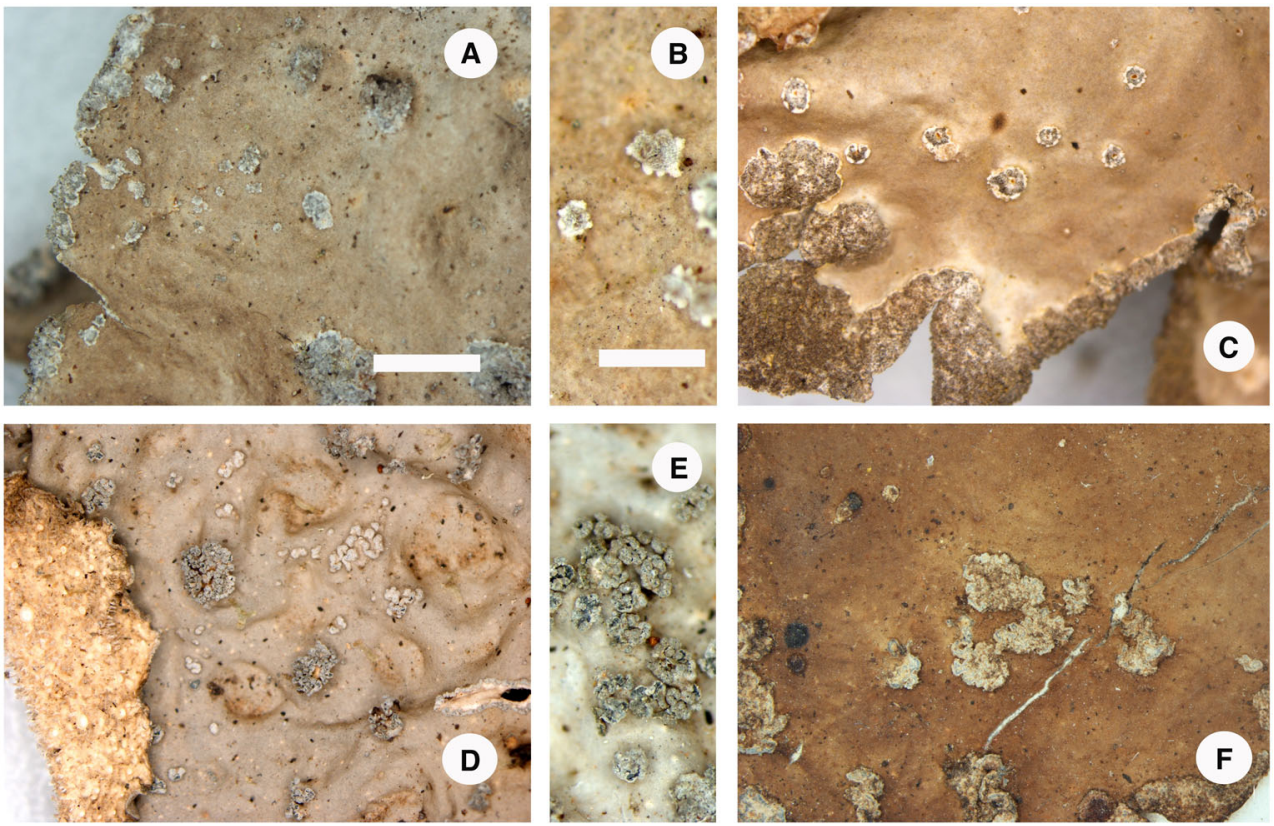

Fig. 9 Sticta limbata (Sm.) Ach. and Sticta umbilicariiformis Hochst. ex Flot.: comparison of soralia production. a-c $S$. limbata with typical soralia emerging from under the cortex and with triangular remnants of that roof on their margins. d-f Sticta umbilicariiformis with typical dactyls emerging from laminal bulges, and developing broken pustules, never producing genuine soralia. f Upper surface of the type material with flattened and compacted pustules. a, c Gomera, Sep. 2011, P. van den Boom 46085, LG, c Ireland/Kerry, 02.2014, E. Sérusiaux s.n., LG, d, e Rwanda, Oct. 2009, E. Sérusiaux s.n., LG, f Ethiopia, type collection. Scale bars: a, c, d, f $2 \mathrm{~mm}$ (scale in a), b, e $1 \mathrm{~mm}$ (scale in b)

\section{Notes:}

of isodiametric cells, $8-14 \mu \mathrm{m}$ in diam. and with a $2-2.5 \mu \mathrm{m}$ thick wall. Lower primary tomentum agglutinated in fascicles, with more than 20 unbranched, cylindrical, usually intertwined hyphae, with cells $15-22 \times 5-6 \mu \mathrm{m}$ and with a c. $1.5 \mu \mathrm{m}$ thick wall; no budding cells seen. Lower secondary tomentum not seen. Cyphellae membrane with outer cells never producing papillae.

No substances detected by TLC.

Nomenclature and typification: the lectotype has been designated by Galloway (1994: 259).

Ecology: on mossy trees and rocks within forests or at their edges, incl. parkland conditions, probably less demanding than other species of the genus as the species can be seen in urban parks in the Western Pyrenees (France and Spain); in Macaronesia, on trees and mossy rocks within the laurisilva and in Erica-Myrica stands (Fayal-Brezal), especially in the most humid localities.

Distribution: Sticta limbata has been reported from many parts of the world; besides Europe, Macaronesia and North America (Galloway and Thomas 2004), it is mentioned in South America (Galloway 1994), East Africa (Swinscow and Krog 1988), Australia (Galloway 2001) and New Zealand (Galloway 2007). Considering the ITS sequences currently available on GenBank and those available to us, and the confusion with $S$. umbilicariiformis (see below), we consider the species to be correctly identified only from continental Europe, Macaronesia, and North America (material examined only from the West Coast).
1. In a European context, S. limbata is easily distinguished as it is the only sorediate species. In a wider context, it has been confused with $S$. umbilicariiformis Hochsc. ex Flotow, a species described from Ethiopia, and whose nomenclature and typification are detailed below. S. umbilicariiformis is easily distinguished from S. limbata by its mainly laminal pustules, erupting from irregularly rounded swellings to form dactyls (sensu Krog and Swinscow 1979) or complex hollow isidioid structures, never forming genuine soredia, and its large (up to 12$15 \mathrm{~cm}$ in diam.), foveolate thallus. The type collection has been examined and matches recent and luxuriant collections recently gathered in the Volcanoes National Park in Rwanda (the so-called Virunga range). The 4-loci phylogenetical tree produced for this study (Fig. 2) clearly demonstrates that two species are involved. Further S. umbilicariiformis can produce apothecia on thalli with soralia (incl. the type collection). Non-sorediate specimens have been sampled and cannot be resolved as a different entity, either with 4-loci phylogenetical inferences nor with ITS haplotype network construction (data not shown).

Sticta umbilicariiformis Hochst. ex Flot. [as "umbilicariaeformis"], in Flotow J. von, Linnaea 4: 16, 1843.

= Stictina limbata var. umbilicariiformis (Hochst. ex Flot.) Nyl., Synop. Lich. 1: 347, 1860. 
= Sticta limbata var. umbilicariiformis (Hochst. ex Flot.) Zahlbr. Cat. Lich. Univ. 3: 392, 1925.

Type: Ethiopia, "In truncis Ericarum lateris borealis montis alpini Silke" (H-Nyl. s.n. !; material here selected as the lectotype).

Typical material of S. umbilicariiformis is currently known only from the Albertine Rift in East Africa, but the species is likely to be present elsewhere in East Africa. Indeed, Swinscow and Krog (1988) failed to distinguish it from $S$. limbata, which is assumed to be "widespread in cooler parts of the tropics and in temperate regions". Earlier workers, however, did use the epithet umbilicariiformis, either as a variety (Zahlbruckner and Hauman 1936) or as a species (Frey 1967) to name this species in the Ruwenzori range and in the Virunga volcanoes (both montane ranges included in the Albertine Rift). The description of S. limbata from Chile (Galloway 1994) points to soredia in erose, marginal soralia, or in scattered, rounded, pustular laminal soralia usually close to lobes margins, coarsely granular [...], a description that would better fit $S$. umbilicariiformis than $S$. limbata; the same remark applies to the description of $S$. limbata in the Sonoran Desert Region (North America: Galloway and Thomas 2004), Australia (Galloway 2001) and New Zealand (Galloway 2007). S. umbilicariiformis might thus be widespread in both hemispheres.

2. Within the first phylogeny of the genus provided by Moncada et al. (2014a) focusing on species from Colombia, S. limbata is resolved within the S. humboldtii clade, comprising the eponym species and S. fuliginosa together with several undescribed ones.

3. As detailed in the section on S. fuliginosa, this species and S. limbata are very closely related and the ITS of the latter differs from the non-European accessions of S. fuliginosa by a single substitution in ITS1. There is, however, one exception as an accession of $S$. limbata from the Pacific Northwest (AY173391: McDonald et al. 2003) has the ITS of the non-European material of $S$. fuliginosa. One accession of $S$. limbata from USA/California (accession JN857309, Fedrowtiz et al. 2012) and two accessions of the same species that we could produce from material from Canada/British Columbia all have the same ITS as our accessions from continental Europe and Macaronesia. Indeed, all ITS sequences of $S$. limbata have strictly the same ITS, except for one substitution in ITS1 for an accession from the Pacific Northwest (in an otherwise invariable region) and one indel in ITS2 (also in an otherwise invariable region) for an accession from Tenerife (Fig. 3).

Selected specimens examined for S. limbata: Canada, British Columbia, 2009, T. Goward 09-246 (LG, hb.
Goward). France, Brittany, Brest, Nov. 2013, A. Gérault s.n. (LG, hb. A. Gérault). Ireland, Kerry, S. of Killarney, N $52^{\circ} 01^{\prime} 05^{\prime \prime} \mathrm{W} 09^{\circ} 30^{\prime} 15^{\prime \prime}, 30 \mathrm{~m}$, Feb. 2014, Quercus forest, E. Sérusiaux s.n. (LG). Portugal, Azores, Pico Is., 2011, P. Divakar s.n. (LG). Ibid., Lagoa do Paúl, N 38²6'10.69" W $28^{\circ} 12^{\prime 2} 28.07^{\prime \prime}, 950 \mathrm{~m}$, July 2014, natural thickets dominated by Juniperus brevifolia, E. Sérusiaux s.n. (LG). Spain: Canary Is., Gomera, Garajonay National Park, N 2807.39' W $17^{\circ} 12.65^{\prime}, 1050 \mathrm{~m}$, Sept. 2011, degraded laurisilva, P. van den Boom 46085 (hb. van den Boom). Ibid., Gran

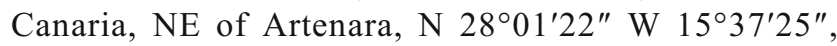
1400 m, May 2011, Pinus canariensis open woodland, E. Sérusiaux s.n. (LG). United Kingdom, Scotland, Argyll, N 56 $6^{\circ} 14^{\prime} 44^{\prime \prime} \mathrm{W} 05^{\circ} 38^{\prime} 19^{\prime \prime}, 35 \mathrm{~m}, 07.2011$, Corylus thicket, B.J. Coppins s.n. (LG).

Selected specimen examined for S. umbilicariiformis: Rwanda, Volcanoes National Park, Sabynyo, S $01^{\circ} 24.01^{\prime}$ E 029 35.15', 2880-2900 m, Oct. 2009, dense thickets, E. Sérusiaux s.n. (LG).

Sticta sylvatica (Huds.) Ach. Methodus Lichenum, p. 281, 1803. (Fig. 10)

Mycobank \# 406401

Bas.: Lichen sylvaticus Hudson, Flora Anglica, vol. 2: 721, 1778.

Type: Icon. In Dillenius, Historia Muscorum, tabl. 27, Fig. 101, 1742 (lectotype, designated by Jørgensen and Tønsberg, Nordic Lichen Flora 3: 145, 2007); corresponding specimen in herb. Dillenius (OXF !, epitype, designated by Jørgensen and Tønsberg, Nordic Lichen Flora 3: 145, 2007).

Thallus usually rounded or fan-shaped in outline, rarely irregular, $1-5 \mathrm{~cm}$ in diam. but able to form larger thalli or colonies of thalli in suitable conditions, up to $10-20 \mathrm{~cm}$ across, with several thalli intermingled and overlapping each other, subcoriaceous, but brittle when dry, branching mostly dichotomous with 1-3(-5) ramifications per main lobe; stipe absent. Lobes slightly ascending and dichotomously branched (more rarely polytomous or irregular), typically involute and thus forming slightly concave fan-shaped forms, $0.4-0.8 \mathrm{~cm}$ wide, laciniate or slightly flabellate, overlapping, ascending when dry, especially for young lobes, with rounded to irregular apices, margins slightly swollen or not, rarely dissected or irregularly lacerate. Upper surface usually dark brown when wet, paler and sometimes bluish grey when dry, usually glossy, typically foveolate or scrobiculate, with shallowly reticulated ridges, but not maculate. Cilia usually absent, but frequently detected between the main lobes, where they are scattered and mimic primary tomentum, simple, white to pale, less than $0.5 \mathrm{~mm}$ long. Isidia always present, developing mainly on lobes margins or on ridges of the upper surface, sometimes covering large parts of the thallus, globulose and developing coralloid masses, up to $0.5 \mathrm{~mm}$ high and in diam., formed of an accumulation of globose or irregular enflated entities, very brittle and easily detached from the thallus, dark 
Fig. 10 Sticta sylvatica (Huds.) Ach. a Thalli on leaning Quercus (Ireland/Kerry, Feb. 2014, photograph taken in the field). $\mathbf{b}$ Well-developed and ascending thalli on Fagus (France/Vosges, June 2014, photograph taken in the field). c, f Upper glossy surface, typically foveolate (c) and with scattered marginal cilia (f). d, e Dark (almost black) lower surface with conspicuous cyphellae and abundant primary tomentum. g Section through the upper paraplectenchymatous cortex, with upper layer made of much smaller cells. h Primary tomentum. c-h France/Brittany, Nov. 2013, A. Gérault s.n. (LG). Scale bars: c, $\mathbf{d} 2 \mathrm{~mm}$ (scale in c), e $0.5 \mathrm{~mm}, \mathbf{f} 1 \mathrm{~mm}, \mathbf{g}, \mathbf{h} 10 \mu \mathrm{m}$
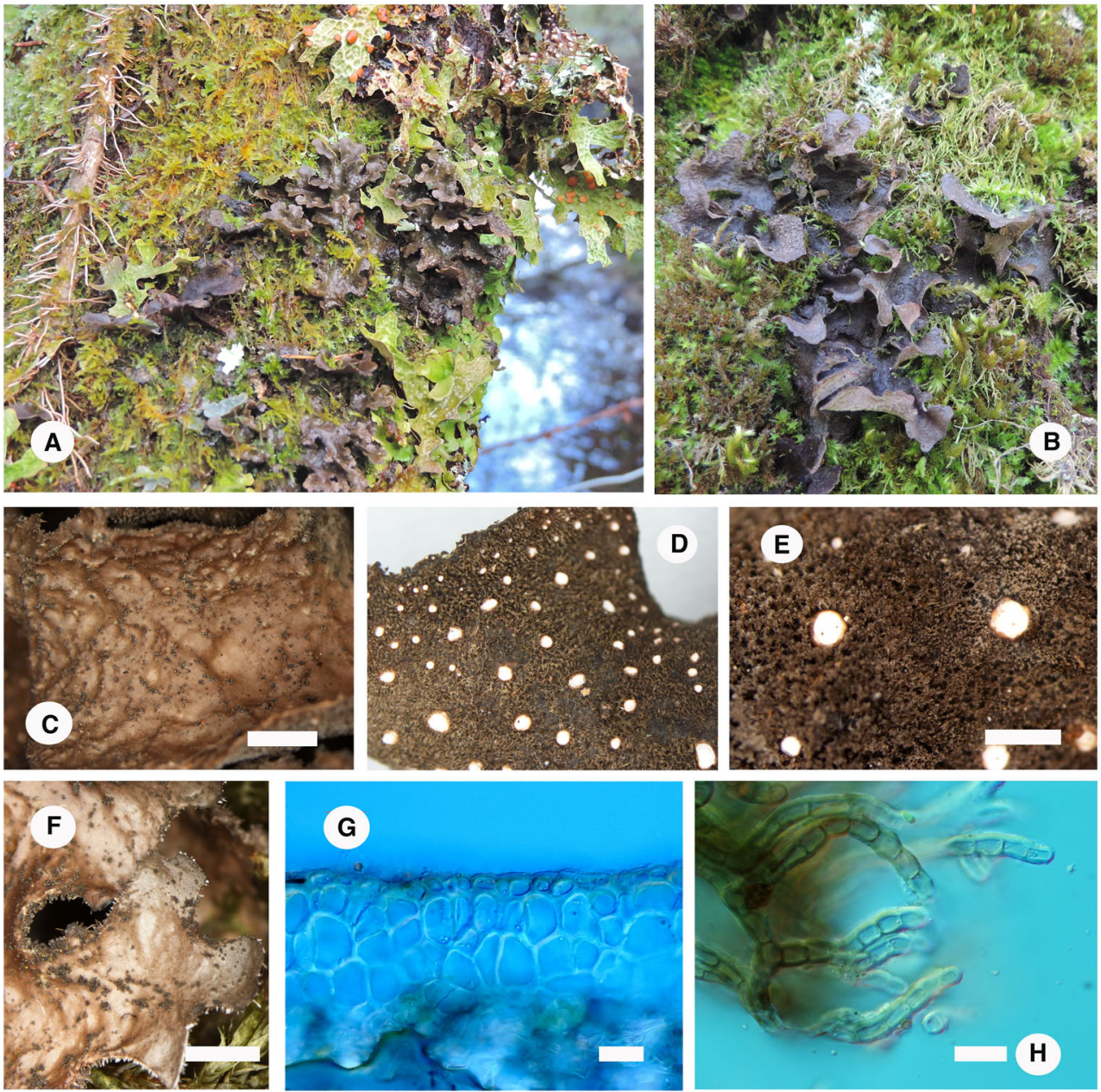

brown to almost black. Lower surface uneven or slightly foveolate, brown to dark brown, to almost black; primary tomentum sometimes absent on the edges of lobes but most usually abundant throughout and dark brown to almost black, forming a spongious mat when well-developed. Cyphellae always present on the lower surface, dispersed, sometimes more or less aggregated, rounded or slightly irregular, 20-40 per $\mathrm{cm}^{2}$ or $>40$ per $\mathrm{cm}^{2}$ near the lobe edges, $0.8-1.1 \mathrm{~mm}$ in diam., erumpent and slighlty involute, outer wall sometimes brown or dark brown, and pore $0.5-0.7 \mathrm{~mm}$ in diam. Apothecia and pycnidia never produced.

Upper cortex paraplectenchymatous, 30-40 $\mu \mathrm{m}$ high, made of 3-4 layers of rounded to isodiametric cells, c. 10$15 \mu \mathrm{m}$ in diam. with a $1.5-2 \mu \mathrm{m}$ thick wall; outer layer distinct, made of a single row of smaller cells (c. 5-8 $\mu \mathrm{m}$ in diam.) with thicker walls $($ c. $3 \mu \mathrm{m})$. Photobiont layer c. 20-25 $\mu \mathrm{m}$ thick, made of Nostoc colonies, forming a continuous layer under the upper cortex, sometimes quite thin and discontinuous, not or very rarely agglomerated in compact, ovoid masses, tightly encompassed by hyphae forming rounded to angular cells and wrapping the Nostoc cells. Medulla white and lax, 50-60 $\mu \mathrm{m}$ thick. Lower cortex paraplectenchymatous, 20-30 $\mu \mathrm{m}$ high, with 2-4 layers of isodiametric cells $8-15 \mu \mathrm{m}$ in diam., with $2 \mu \mathrm{m}$ thick walls. Lower primary tomentum formed of bunches of cylindrical hyphae, $0.1-0.4 \mathrm{~mm}$ long, agglutinated to each other except at their tips and typically intertwined, made of elongated cells with thick and dark brown walls (lumina: 615×4-6 $\mu \mathrm{m}$; walls: $1.5-2 \mu \mathrm{m}$ thick); cells sometimes slightly inflated, especially near the branching nodes; apical cells distinctly shorter (c. 5-7 $\mu \mathrm{m}$ long), slightly moniliform and probably able to be dispersed as single entities.

Cyphellae with basal membrane white, made of 1-2 layers of rounded or rarely irregular cells, $9-14 \mu \mathrm{m}$ in diam., sometimes budding and producing papillae c. $4 \mu \mathrm{m}$ in diam.

No substances detected by TLC.

Nomenclature and typification: the epitype specimen was designated by Jørgensen \& Tønsberg (Nordic Lichen Flora 3: $146,2007)$ and can be examined online at the Oxford Herbarium web site (http://herbaria.plants.ox.ac.uk/bol/ MUSCORUM/image/HM-sheet 073.jpg/Zoom?width= $760 \mathrm{px} \&$ height $=760 \mathrm{px}$ ). This specimen has been examined (Fig. 3) and corresponds to the populations from Western Europe assigned to this epithet in the British Isles (Smith et al. 2009), Germany (Wirth et al. 2013) and Norway and 
Sweden (Jørgensen and Tønsberg 2007). Further, we could produce ITS sequences for the four sampled localities: France/Brittany and Vosges, U.K./Somerset and Ireland/ Kerry. They are all strictly identical: we thus consider that they represent $S$. sylvatica.

Ecology: on mossy trees within forests or at their edges, incl. parkland conditions in oceanic climate, found in the montane zone (Fagus sylvatica and Abies alba mixed forest) at c. $1000 \mathrm{~m}$ elev. down to Quercus-dominated forest at sea level.

Distribution: Sticta sylvatica has been mentioned from all continents except Australia: Europe (Austria: Hafellner and Türk 2001; British Isles: Smith et al. 2009; Germany: Wirth et al. 2013; Norway and Sweden: Jørgensen and Tønsberg 2007; Portugal and Spain: Burgaz and Martínez 2003; Macaronesia: Canary Is. and Madeira: Hafellner 1995 and Azores: http://www.azoresbioportal.angra.uac.pt. accessed on Feb. 11th, 2015), NY, USA (Harris 2004) and Sonoran region (Galloway and Thomas 2004), South Africa (Doidge 1950), Micronesia in the Pacific Ocean (Elix and McCarthy 1998), Taiwan (Aptroot et al. 2002), and Peru (Soukup 1965). In their account for the Sonora region, Galloway and Thomas (2004) further added Greenland and the Mediterranean region. Considering the ITS sequences currently published (Moncada et al. 2014a) and those available to us, we consider the species to be correctly identified only from continental Europe and the Andes in Colombia. The large and recent collections available to us from Macaronesia and Africa (incl. Madagascar, Mauritius and Reunion) did not yield any specimen referable to $S$. sylvatica. We consider that data from Macaronesia either refers to $S$. fuliginosa or $S$. atlantica.

Notes

1. Sticta sylvatica is easily distinguished by its dichotomously branched and involute lobes, with a dark brown upper surface which is typically glossy and foveolate to scrobiculate, and coralloid dark isidia developing mainly at the lobes margins and on ridges on the upper surface. S. atlantica might be confused with it and mainly differs by its isidia always developing on swellings on the upper surface, or along small ridges; further $S$. sylvatica has a brown to black lower surface usually densely covered by a primary tomentum forming a spongious mat when welldeveloped, while $S$. atlantica has a primary tomentum made of distinct fasciculate to penicillate hairs, easily distinguished from one another in young lobes, eventually forming spongy masses but never dark brown to black.

2. Within the first phylogeny of the genus provided by Moncada et al. (2014a) focusing on species from Colombia, S. sylvatica is resolved within the S. kunthii clade, the most derived group in that phylogeny. More data are, however, needed to assess its relationships within that clade.
3. All ITS sequences from the four localities sampled are strictly identical. Nearly identical ITS sequences were retrieved from GenBank for three collections from Colombia (Moncada et al. 2014a). One accession (KC732581) is identical with our material from Western Europe, except for one indel in ITS2; accession KC732518 differs by five substitutions and one indel in ITS1 and three substitutions in ITS2 and may thus represent a distinct species; the third accession (KC732574) is incomplete and cannot be properly assessed.

One ITS accession from NC, USA (JX064536) referred to $S$. sylvatica by its authors (Hodkinson et al. 2014) is strictly identical with Sticta fuliginosa as circumscribed in this paper. A collection from British Columbia (Canada) identified as $S$. cfr. sylvatica by its collector (T. Goward, \# 2009-246) is almost identical to an accession (AY124095) from China (Lohtander et al. 2002, sub S. fuliginosa) and other collections from the Canary Islands (Gomera and Gran Canaria). These sequences are very different and are referred to sp. 1 in our phylogenetic tree. This taxon is unamed and is not related to S. sylvatica. Therefore, and with the data currently available to us, S. sylvatica does not occur in North America.

Selected specimens examined: Ireland, Kerry, S of Killarney, N 52 $01^{\prime} 05^{\prime \prime} \mathrm{W} 09^{\circ} 30^{\prime} 15^{\prime \prime}, 30 \mathrm{~m}, 2.2014$, Quercus forest, E. Sérusiaux s.n. (LG). France, Brittany, Cahos de St-Herbot, N 48 $20^{\prime} 02^{\prime \prime} \mathrm{W} 03^{\circ} 48^{\prime} 06^{\prime \prime}, 160 \mathrm{~m}$, mixed forest, 11. 2013, A. Gérault s.n. (LG, herb. Gérault). Ibid., Haut-Rhin, Hohneck, N $48^{\circ} 02^{\prime}$ E $07^{\circ} 01^{\prime}$, c. 1000 m, June 2014, open mixed forest, E. Sérusiaux s.n. (LG). United Kingdom, Somerset, Horner woods, N 51 ${ }^{\circ} 10^{\prime} \mathrm{W}$ $03^{\circ} 35^{\prime}$, c. 290 m, Feb. 2014, P. Wolseley s.n. (LG).

\section{Identification of species of Sticta in continental Europe}

\section{ITS barcode}

ITS has been chosen as the Barcode for Fungi (Schoch et al. 2012) and is now widely used as such, although several studies have highlighted the low resolution of this loci in several groups (see for example Magain et al. 2012b for Peltigera sect. Polydactylon and Carlson et al. 2014 for Trametes) or the challenge to reconcile morphological and chemical results with ITS data (see for example Mark et al. 2012 for Vulpicida and Pino-Bodas et al. 2011, 2012a, b, 2013a, b for Cladonia).

Within the genus Sticta, ITS provides an appropriate mean to detect and delimitate species (Moncada et al. 2014a). In the geographical framework of this work (continental Europe), ITS sequences alone provide a quick answer to the task of delimitating species, with one exception detected in the duo 
formed by $S$. fuliginosa and $S$. limbata, two species that cannot be resolved as single entities with 4-loci inferences in a phylogenetic framework.

We identify a $20 \mathrm{bp}$ segment in ITS1 that provides a shorter and accurate way for the recognition of all species of the emblematic and cherished lichen genus Sticta in Europe. Sleepless nights? This title by Tripp and Lendemer (2014) was a quite enigmatic and provocative one to propose guidelines for the description of new species on the basis of molecules only. At least so far, it is not the case with the flagship genus Sticta, but other genera in the Peltigerales do present this challenge (Magain et al. 2012b; Miadlikowska et al. 2014b).

Autapomorphic positions (one to three) are underlined for each species (except for $S$. canariensis which has no such position in this fragment):

Sticta atlantica

Sticta canariensis

Sticta ciliata

Sticta fuliginoides

Sticta fuliginosa

Sticta limbata

Sticta sylvatica

\section{Tentative key to species of Sticta in continental Europe when lichenized with Nostoc}

This tentative key is based on morphological and anatomical data obtained from recently collected specimens for which DNA could be extracted and the ITS barcode amplified. It is tentative because it does not include the variation observed in herbarium material, especially depauperate specimens coming from non-optimal environmental conditions. That variation is large and confusing. Further blind tests to identify small fragments of specimens for which ITS is known to have failed in several cases, especially for the recognition of $S$. ciliata and for the distinction of the duo $S$. fuliginoides/S. fuliginosa. As it is impossible to extract DNA from collections of Sticta older than 2 years, the whole phenotype variation could not be confronted with ITS data. Examination of anatomical characters, especially the papillae on the cyphella membrane, in old herbarium specimens is difficult and may require careful preparation with Phloxin (1\% in water) after pre-treatment in $\mathrm{KOH}$ ( $5 \%$ in water); absence of such papillae must be carefully evaluated. We are, however, convinced that further studies of the genus throughout Europe will bring in more morphological and anatomical information that should allow much easier identification of the recognized species in the field and herbarium material. By all means, for living populations, collecting a single lobe and producing its ITS barcode is the easiest and most reliable way of identification.

1 Thallus always producing soralia, mainly at lobes margins $S$. limbata

(S. limbata is the only species with soralia in continental Europe; otherwise it has rather large, suborbicular lobes with plane and undulating margins)

1 * Thallus never with soralia, always with isidia or phyllidia

2 Thallus with upper surface strongly maculate; margins always and upper surface usually with typical phyllidia $S$. canariensis (cyanomorph)

(The cyanomorph of $S$. canariensis is easily characterized by the combination of strongly maculate upper surface and production of phyllidia)

2* Thallus with upper surface never strongly maculate; isidia most usually coralloid, never developing into typical phyllidia

3 Papillae on cyphella membrane

4 Thallus rounded, monophyllous (and then typically mushroom-like) or with several rounded lobes, hardly dissected, dark brown, rarely pale greyish; margin typically involute, rarely sparsely ciliate on regenerating lobules; thallus rather robust; papillae on cyphella membrane few per cell; apothecia unknown $\boldsymbol{S}$. fuliginoides

(S. fuliginoides almost always have an involute margin and mushroom-like habitus when young)

$4 *$ Thallus rounded to palmate, with lobes rounded (when young) to truncate (when old), dark dull brownish, lead grey or pale greyish; margin usually not involute, most usually ciliate, especially when young; thallus very fragile and easily broken when dry; papillae on cyphella membrane numerous per cell, easily seen in fresh material; apothecia present in well-developed specimens, typically ciliate $\boldsymbol{S}$. ciliata

(S. ciliata is easily recognized by its fragile and irregular thallus with marginal cilia; it is the only fertile species amongst all cyanomorphic species of Sticta in Europe)

3* Papillae absent on cyphella membrane

5 Thallus distinctly branched, almost always dichotomously, typically glossy; lobes involute, shallowing and usually with ascending margins; lower surface usually dark, especially towards the center, strongly contrasting with the white cyphellae $\boldsymbol{S}$. sylvatica

(S. sylvatica typically have dichotomously branched thallus, with involute lobes and a black lower surface)

5* Thallus not distinctly branched, although lobes can be lacerate or dissected, not typically glossy; lobes rounded, not shallowing; lower surface usually pale, or brownish, not strongly contrasting with the white cyphellae

6 Lobes surface with distinct swellings, irregular in shape but always present, with isidia developing on their upper parts $\boldsymbol{S}$. atlantica 
(S. atlantica has small and irregular swellings on its upper surface and isidia develop on them)

$6^{*}$ Lobes surface with no or irregular swellings, but rather typically reticulate or scrobiculate, and isidia developing on the edges of these dimples $\boldsymbol{S}$. fuliginosa

( $S$. fuliginosa has no straightforward diagnostic character and can be recognized because it does not have the diagnostic ones of others: no cilia, no mushroom-like appearance, no swellings on upper surface, no dichotomously branched thallus and no papillae on cells of the cyphella membrane)

\section{Conclusions}

With a dedicated sampling in four localities in continental Europe and assembling relevant data from collections available to us, especially from Macaronesia and Africa, we could detect seven species of Sticta in continental Europe, almost doubling the $\alpha$-diversity of the genus for that region. Indeed, besides the very distinct $S$. canariensis and $S$. limbata, we could detect five distinct ITS entities for isidia-producing specimens that would be identified as only two species in all modern floras, namely $S$. fuliginosa and S. sylvatica (Lambinon 1969; Llimona and Hladun 2001; Burgaz and Martínez 2003; Jørgensen and Tønsberg 2007; Smith et al. 2009; Wirth et al. 2013). Thanks to relevant tables of morphological and anatomical characters provided by Moncada et al. (2014a), subtle anatomical and morphological characters came to light and, together with a strongly supported 4-loci molecular phylogeny, permit to distinguish: S. atlantica $\mathrm{sp}$. nov., S. ciliata Tayl., S. fuliginosa, S. fuliginoides sp. nov. and S. sylvatica.

Most probably, such a drastic shift into the molecular era for a lichen genus that has been so much used in biomonitoring studies and biodiversity conservation policy is not a unique case. Indeed, several studies have already demonstrated how poorly supported is the taxonomy of many emblematic taxa when they are challenged by detailed molecular studies. Recent studies show either that the currently accepted species are not recovered as monophyletic and traditional diagnostic morphological characters are highly homoplasious (Leavitt et al. 2015), or that many independent lineages can be distinguished in a single species complex for which no morphological and chemical characters can be recognized. The best examples for the latter case are to be found in Cladonia (Pino-Bodas et al. 2011, 2012a, b, 2013a, b), and examples of the former can be found in the Vulpicida juniperus group (Mark et al. 2012), the Peltigera polydactylon clade (Magain et al. 2012b), or the Tephromela atra group (Muggia et al. 2014). By all means, the most emblematic case is the basiolichen Cora pavonia, very much characteristic of montane forests and paramos in Central and South America, which has been shown on molecular basis to contain at least 126 species, over 110 of them being yet undescribed (Lücking et al. 2014).

We could demonstrate that the rationale of the taxonomy of Sticta in Europe, settled almost two centuries ago by Delise (1826) and for the most part still in use, could not resist a modern analysis. Now, as for several other lichen genera, species of Sticta are widely used as valuable bioindicators for environment and climat monitoring and for forests management and protection. It is unlikely that all seven species have a strictly identical ecology and their identification should improve the use and interpretation of ecological data, especially at fine scales.

Further, beyond the new taxonomy that our study could propose for a well-known and cherished genus, interesting evolutionary patterns came to light:

(1) the two and most easiest species to distinguish one from another ( $S$. fuliginosa vs $S$. limbata) also are the phylogenetically closest in our dataset: their intraspecific variation is very low and their ITS barcode differs only by one substitution. Further one accession of $S$. limbata appears to have the ITS of S. fuliginosa. Moreover, the 4loci phylogenetic analysis could not resolve both species as single entities. Incomplete lineage sorting may easily explain this pattern for this species duo that must have diverged recently.

(2) On the other hand, the largest variation is observed within the resurrected $S$. ciliata, that forms a complex of most probably cryptic species occuring in the Neotropics, Hawaii archipelago, Africa, Macaronesia and Western Europe.

Acknowledgments Field studies in several parts of the world were made possible with the help and advice of local authorities and colleagues, and we would like to mention in particular Rogerlala Andriamiandrisoa, Maarten Brand, Damien Ertz, Eberhard Fischer, Bernard Goffinet, Dorothee Killmann, Tahina Razafindrahaja, and Pieter van den Boom for our field trips in Africa (Congo RDC, Madagascar, Rwan$\mathrm{da}$, and Reunion) and Jeff Malter and Pat Wolseley for the field trip in United Kingdom. Several specimens examined in this paper were also collected by colleagues from Brittany in France (B. Bouffinier, A. Gérault, and F. Séité) whose work and enthusiasm for lichenology can be consulted at http://www.lichensmaritimes.org/ and by Pat Wolseley: we thank them very warmly. We also received valuable material from Brian Coppins from Scotland, Pradeep Divakar from the Azores, Bernard Goffinet from USA/North Carolina and South Africa, Trevor Goward from Canada/British Columbia and Pieter van den Boom from the Canary Islands: we also thank them very warmly. We could examine type collections at the Herbarium of the University of Oxford (OXF), thanks to the warm welcome of Dr. Stephen Harris and Ms Serena Marner, and at the British Museum Herbarium (BM), thanks to the warm welcome of Dr. Holger Thues and Ms Pat Wolseley. The type material of Sticta fuliginosa f. ciliata Degel. could be examined via photographs sent to us by Dr. Stefan Ekman and Anders Nordin: we thank them very warmly. The type material of $S$. umbilicariiformis was made available by Dr. Leena Myllys and we also thank her very warmly. We further thank Ido Cremasco and Laurent Gohy for technical assistance in the molecular laboratory and herbarium at the University of Liège. This paper 
is a part of a large project on Sticta conducted with Bernard Goffinet, Robert Lücking, Bibiana Moncada and Thorsten Lumbsch and funded by the National Science Foundation (USA) under the title "Starting from scratch with Sticta: Evolution, diversification, and conservation of a megadiverse flagship lichen genus" (\# DEB-1354631). We acknowledge the suggestions and data obtained from Dr. Bibiana Moncada and Dr. Robert Lücking at several stages of this study; without those data this work would have progressed with much more difficulties: we thus thank very warmly Bibiana and Robert for their support. When the data used in this study were assembled, Nicolas Magain was a Ph.D. Student at the University of Liège and acknowledges the financial support by FRIA, an organ of the Belgian Scientific Research Foundation. Finally we warmly thank both referees for their critical and helpful notes and suggestions.

\section{References}

Ahti T (1980) Nomenclatural notes on Cladonia species. Lichenologist 12:125-133

Ahti T, Stenroos S (2012) New data on nomenclature, taxonomy and distribution of some species of the lichen genus Cladonia. Botanica Complutensis 36:31-34

Anders J (1928) Die Strauch- und Laubflechten Mitteleuropas. Anleitung zum Bestimmen der in Mitteleuropa vorkommenden Strauch- und Laubflechten. Fischer, Jena

Aptroot A (2008) Sticta alpinotropica, a new saxicolous lichen species from the alpine zone of Mt. Wilhelm, Papua New Guinea. Lichenologist 40:419-422

Aptroot A, Sparrius LB, Lai MJ (2002) New Taiwan macrolichens. Mycotaxon 84:281-292

Aptroot A, Jordaens D, Sparrius L, Spier L, van den Broeck D (2007) Korstmossen in Finistère (Bretagne). Buxbaumiella 78:52-64

Armaleo D, Clerc P (1991) Lichen chimeras: DNA analysis suggests that one fungus forms two morphotypes. Exp Mycol 15:1-10

Bory de Saint-Vincent JBGM (1804) Voyages dans les quatre principales îles des mers d'Afrique. F. Buisson, Paris

Brodo IM (1994) Sticta canariensis: a new lichen for North America. Evansia 11:76-77

Burgaz AR, Martínez I (2003) Flora Liquenológica Ibérica. Peltigerales: Lobariaceae, Nephromataceae, Peltigeraceae. Sociedad Española de Liquenología (SEL), Murcia

Carlson A, Justo A, Hibbett DS (2014) Species delimitation in Trametes: A comparison of ITS, RPB1, RPB2 and TEF1 gene phylogenies. Mycologia 106:735-745

Castresana J (2000) Selection of conserved blocks from multiple alignments for their use in phylogenetic analysis. Mol Biol Evol 17:540 552

Clement M, Posada D, Crandall KA (2000) TCS: a computer program to estimate gene genealogies. Mol Ecol 9:1657-1659

Coppins BJ (1971) Field meeting in Brittany. Lichenologist 5:149-169

Coppins AM, Coppins BJ (2002) Indices of Ecological Continuity for Woodland Epiphytic Lichen Habitats in the British Isles. British Lichen Society, Wimbledon

Cornejo C, Chabanenko S, Scheidegger C (2009) Phylogenetic analysis indicates transitions from vegetative to sexual reproduction in the Lobaria retigera group (Lecanoromycetes, Ascomycota). Lichenologist 4:275-284

Cornejo C, Scheidegger C (2010) Lobaria macaronesica sp. nov., and the phylogeny of Lobaria sect. Lobaria (Lobariaceae) in Macaronesia. Bryologist 113:590-604

Cubero OF, Crespo A, Fatehi J, Bridge PD (1999) DNA extraction and PCR amplification method suitable for fresh, herbarium-stored, lichenized, and other fungi. Plant Syst Evol 216:243-249
Degelius G (1935) Das ozeanische Element der Strauch- und Laubflechtenflora von Skandinavien. Acta Phytogeogr Suecica 7: $1-411$

Degelius G (1941) Lichens from the Azores, mainly collected by Dr. H. Persson. Göteborgs Kungliga Vetenskaps- och Vitterhets-samhälles Handlinger, Sjätte Följden, ser. B 1:45 pp+3 pl

Delise D (1826; « $1825 »)$ Histoire de Lichens. Genre Sticta. Chalopin fils, Caen

Doering M, Coxson D (2010) Riparian alder ecosystems as epiphytic lichen refugia in sub-boreal spruce forests of British Columbia. Botany 88:144-157

Doidge EM (1950) The South African fungi and lichens to the end of 1945. Bothalia 5:1-1094

Elix JA, McCarthy PM (1998) Catalogue of the Lichens of the Smaller Pacific Islands. Bibliotheca Lichenologica 70, Cramer, Stuttgart

Ellis CJ (2012) Lichen epiphyte diversity: a species, community and traitbased review. Pers Plant Ecol Evol Syst 14:131-152

Ellis CJ (2013) A risk-based model of climate change threat: hazard, exposure, and vulnerability in the ecology of lichen epiphytes. Botany 91:1-11

Fedrowtiz K, Kaasalainen U, Rikkinen J (2012) Geographic mosaic of symbiont selectivity in a genus of epiphytic cyanolichens. Ecol Evol 2:2291-2303

Flörke HG (1809) Kleine Licheneflora der Inseln Frankreich und Bourbon nach den Entdeckgen des Herrn Capitains Bory de St. Vincent. Magazin Ges Naturforscher Freunde Berlin 2:122-128

Frey E (1967) Die lichenologischen Ergebnisse der Forschungsreisen des Dr. Hans Ulrich Stauffer in Zentralafrika (Virunga-Vulkane 1954/55) und Sudafrika-Australien-Ozeanien-USA 1963/64. Bot Jahrb 86:209-255

Galloway DJ (1994) Studies on the lichen genus Sticta (Schreber) Ach.: I. Southern South American species. Lichenologist 26:223-282

Galloway DJ (1995) Studies on the lichen genus Sticta (Schreber) Ach.: III. Notes on species described by Bory de St-Vincent, William Hooker, and Delise, between 1804 and 1825. Nova Hedwigia 61: $147-188$

Galloway DJ (2001) Sticta. In: McCarthy PM (ed) Flora of Australia, vol 58A, Lichens 3. ABRS, CSIRO Australia, pp 78-97

Galloway DJ (2007) Flora of New Zealand. Manaaki Whenua Press, Lincoln, Lichens. Revised second edition including lichen-forming and lichenicolous fungi

Galloway DJ (2015) Contribution to a history of New Zealand lichenology 5. James Murray (1923-1961). Phytotaxa 198:1-67

Galloway DJ, James PW (1986) Species of Pseudocyphellaria Vainio (Lichenes), recorded in Delise's "Histoire des Lichens: Genre Sticta". Nova Hedwigia 42:423-490

Galloway DJ, Thomas MA (2004) Sticta. In: Nash TH III, Ryan BD, Diederich P, Gries C, Bungartz F (eds) Lichen Flora of the greater Sonoran desert region, vol 2, Lichens unlimited. Arizona State University, Tempe, pp 513-524

Gardes M, Bruns TD (1993) ITS primers with enhanced specificity for basidiomycetes-application to the identification of mycorrhizae and rusts. Mol Ecol 2:113-118

Giavarini V (2012) Field meeting in Killarney, South West Ireland. Brit Lichen Soc Bull 110:85-93

Giordani P, Calatayud V, Stofer S, Seidling W, Granke O, Fischer R (2014) Detecting the nitrogen critical loads on European forests by means of epiphytic lichens. A signal-to-noise evaluation. For Ecol Manag 311:29-40

Hafellner J (1995) A new checklist of lichens and lichenicolous fungi of insular Laurimacaronesia including a lichenological bibliography for the area. Fritschiana 5:1-132

Hafellner J, Türk R (2001) Die lichenisierten Pilze Österreichs - eine Checkliste der bisher nachgewiesenen Arten mit verbreitungsangaben. Stapfia 76:1-167 
Harmand J (1909) Lichens de France. Catalogue systématique et descriptif. IV. Phyllodés. Librairie des sciences naturelles, Paul Klincksieck, Paris

Harris RC (2004) A preliminary list of the lichens of New York. Opusc Philolichenum 1:55-73

Hodkinson BP, Lendemer JC, McDonald T, Harris RC (2014) The status of Sticta sylvatica, an exceedingly rare lichen species, in Eastern North America. Evansia 31:17-24

Högnabba F, Stenroos S, Thell A (2009) Phylogenetic relationship and evolution of photobiont associations in the Lobariaceae (Peltigerales, Lecanoromycetes, Ascomycota). Bibl Lichenol 100: 157-187

Huelsenbeck JP, Ronquist F (2001) MRBAYES: Bayesian inference of phylogenetic trees. Bioinformatics 17:754-755

Hultengren S (2005) Åtgärdsprogram för bevarande av ärrlavar (Släktet Sticta) NATURVÅRDVERKET, Stockholm, $38 \mathrm{pp}$. Available at http://www.naturvardsverket.se/Documents/publikationer/6205470-8.pdf?pid=3097

Jørgensen PM, Tønsberg T (2007) Lobariaceae. Nordic Lichen Flora 3: $77-86$

Katoh K, Standley DM (2013) MAFFT multiple sequence alignment software version 7: improvements in performance and usability. Mol Biol Evol 30:772-780

Kauff F, Lutzoni F (2002) Phylogeny of the Gyalectales and Ostropales (Ascomycota, Fungi): among and within order relationships based on nuclear ribosomal RNA small and large subunits. Mol Phylogenet Evol 25:138-156

Krog H, Swinscow TDV (1979) Parmelia subgenus Hypotrachyna in East Africa. Nor J Bot 26:11-43

Lambinon, J (1969) Les Lichens. Morphologie, Biologie, Systematique, Ecologie. Introduction a l'Etude des Lichens de Belgique et des Regions Voisines. Les Naturalistes Belges, Bruxelles

Lanfear R, Calcott B, Ho SY, Guindon S (2012) PartitionFinder: combined selection of partitioning schemes and substitution models for phylogenetic analyses. Mol Biol Evol 29:1695-1701

Laundon JR (1984) The typification of Withering's neglected lichens. Lichenologist 16:211-239

Leavitt SD, Moreau CS, Lumbsch HT (2015) The dynamic discipline of species delimitation: progress toward effectively recognizing species boundaries in natural populations. In: Upreti DK et al (eds) Recent advances in lichenology, Modern methods and approaches in lichen systematics and culture techniques, vol 2. Springer, India, pp $11-44$

Llimona X, Hladun NL (2001) Checklist of the lichens and lichenicolous fungi of the Iberian Peninsula and Balearic Islands. Bocconea 14:1581

Lohtander K, Oksanen I, Rikkinen J (2002) A phylogenetic study of Nephroma (lichen-forming Ascomycota). Mycol Res 106:777-787

Lücking R, Dal-Forno M, Sikaroodi M, Gillevet PM, Bungartz F, Moncada B, Yańez-Ayabaca A, Chaves JL, Coca LF, Lawrey JD (2014) A single macrolichen constitutes hundreds of unrecognized species. Proc Natl Acad Sci U S A 111:11091-11096

Lumbsch HT, Ahti T, Altermann S et al (2011) One hundred new species of lichenized fungi: a signature of undiscovered global diversity. Phytotaxa 18:1-127

Mackay JT (1836) Flora hibernica. William Curry Jun. and Co., Dublin

Maddison D, Maddison W (2005) MacClade v. 4.08. Sinauer Assoc., Sunderland

Magain N, Sérusiaux E (2014) Do photobiont switch and cephalodia emancipation act as evolutionary drivers in the lichen symbiosis? A case study in the Pannariaceae (Peltigerales). PLoS ONE 9(2) doi: 10.1371/journal.pone.0089876

Magain N, Goffinet B, Sérusiaux E (2012a) Further photomorphs in the lichen family Lobariaceae from Reunion (Mascarene archipelago) with notes on the phylogeny of Dendriscocaulon cyanomorphs. Bryologist 115:243-254
Magain, N, Miadlikowska J, Lutzoni F, Goffinet B, Sérusiaux E (2012b) Multilocus-based phylogeny and species recognition within the cosmopolitan Peltigera neopolydactyla-dolichorhiza complex. International Association for Lichenology, 7th Symposium, Bangkok (Thailland), available at http://orbi.ulg.ac.be/handle/2268/ 128820

Mark K, Saag L, Saag A, Thell A, Randlane T (2012) Testing morphology-based delimitation of Vulpicida juniperinus and V. tubulosus (Parmeliaceae) using three molecular markers. Lichenologist 44:757-772

Matheny PB, Liu YJ, Ammirati JF, Hall BD (2002) Using RPB1 sequences to improve phylogenetic inference among mushrooms (Inocybe, Agaricales). Am J Bot 89:688-698

McDonald T, Miadlikowska J, Lutzoni F (2003) The lichen genus Sticta in the Great Smoky Mountains: a phylogenetic study of morphologial, chemical, and molecular data. Bryologist 106:61-79

Miadlikowska J, Kauff F, Högnabba F, Oliver JC, Molnár K et al (2014a) A multigene phylogenetic synthesis for the class Lecanoromycetes (Ascomycota): 1307 fungi representing 1139 infrageneric taxa, 317 genera and 66 families. Mol Phylogenet Evol 79:132-168

Miadlikowska J, Richardson D, Magain N, Ball B, Anderson F, Cameron R, Lendemer J, Truong C, Lutzoni F (2014b) Phylogenetic placement, species delimitation, and cyanobiont identity of endangered aquatic Peltigera species (lichen-forming Ascomycota, Lecanoromycetes). Am J Bot 101:1141-1156

Miller MA, Pfeiffer W, Schwartz T (2010) Creating the CIPRES Science Gateway for inference of large phylogenetic trees. IEEE 1-8

Moncada B, Lücking R (2012) Ten new species of Sticta and counting: Colombia as a hot spot for unrecognized diversification in a "conspicuous" macrolichen genus. Phytotaxa 74:1-29

Moncada B, Lücking R, Betancourt L (2013a) Phylogeny of the Lobariaceae (lichenized Ascomycota: Peltigerales), with a reappraisal of the genus Lobariella. Lichenologist 45:203-263

Moncada B, Coca LF, Lücking R (2013b) Neotropical members of Sticta (lichenized Ascomycota: Lobariaceae) forming photosymbiodemes, with the description of seven new species. Bryologist 116:169-200

Moncada B, Lücking R, Coca LF (2013c) Six new apotheciate species of Sticta (lichenized Ascomycota: Lobariaceae) from the Colombian Andes. Lichenologist 45:635-656

Moncada B, Lücking R, Suárez A (2014a) Molecular phylogeny of the genus Sticta (lichenized Ascomycota: Lobariaceae) in Colombia. Fungal Divers 64:205-231

Moncada B, Aguirre J, Lücking R (2014b) Ecogeografía del género Sticta (Ascomycota liquenizados: Lobariaceae) en Colombia. Rev Biol Trop 62:257-272

Muggia L, Pérez-Ortega S, Fryday A, Spribille T, Grube M (2014) Global assessment of genetic variation and phenotypic plasticity in the lichen-forming species Tephromela atra. Fungal Divers 64:233251

Nimis PL (1993) The Lichens of Italy. Museo Regionale di Scienze Naturali, Torino

Nylander JA, Wilgenbusch JC, Warren DL, Swofford DL (2008) AWTY (are we there yet?): a system for graphical exploration of MCMC convergence in Bayesian phylogenetics. Bioinformatics 24:581583

Orange A, James PW, White FJ (2010) Microchemical methods for the identification of lichens. The British Lichen Society, London

Øvstedal DG, Gremmen NJM (2010) New lichen species from Tristan da Cunha and Gough Island. Folia Crypt Estonia 47:43-49

Ozenda P, Clauzade G (1970) Les Lichens. Etude Biologique et Flore Illustrée. Masson \& Cie, Paris

Pino-Bodas R, Burgaz AR, Martín MP, Lumbsch HT (2011) Phenotypical plasticity and homoplasy complicate species delimitation in the Cladonia gracilis group (Cladoniaceae, Ascomycota). Org Divers Evol 11:343-355 
Pino-Bodas R, Martín MP, Burgaz AR (2012a) Cladonia subturgida and C. iberica (Cladoniaceae) form a single, morphologically and chemically polymorphic species. Mycol Prog 11:269-278

Pino-Bodas R, Burgaz AR, Martín MP, Lumbsch HT (2012b) Species delimitations in the Cladonia cariosa group (Cladoniaceae, Ascomycota). Lichenologist 44:121-135

Pino-Bodas R, Martín MP, Burgaz AR, Lumbsch HT (2013a) Species delimitation in Cladonia (Ascomycota): a challenge to the DNA barcoding philosophy. Mol Ecol Resour 13:1058-1068

Pino-Bodas R, Ahti T, Stenroos S, Martín MP, Burgaz AR (2013b) Multilocus approach to species recognition in the Cladonia humilis complex (Cladoniaceae, Ascomycota). Am J Bot 100:664-678

Poelt J (1963) Bestimmungsschuessel der hoeheren Flechten von Europa. Mitt Bot Staatssammlung München 4:301-571

Poelt J (1969) Bestimmungsschlussel Europaischer Flechten. Verlag von $\mathrm{J}$, Cramer, Lehre

Radies DN, Coxson DS (2004) Macrolichen colonization on 120-140 year old Tsuga heterophylla in wet temperate rainforests of centralinterior British Columbia: a comparison of lichen response to evenaged versus old-growth stand structures. Lichenologist 36:235-247

Radies DN, Coxson DS, Johnson C, Konwicki K (2009) Predicting canopy macrolichen diversity and abundance within old-growth inland temperate rainforests. For Ecol Manag 259:86-97

Rambaut A, Drummond A (2007) Tracer. Version 1.5. Available at http:// tree.bio.ed.ac.uk/software/tracer/

Root HT, Geise LH, Jovan S, Neitlich P (2015) Epiphytic macrolichen indication of air quality and climate in interior forested mountains of the Pacific Northwest, USA. Ecol Indic 53:95-105

Roux C (2013) Catalogue des lichens et des champignons lichénicoles de Corse. Bull Assoc Fr Lichénol 38:187-326

Roux C, Monnat JY, Van Haluwyn D et al (2014) Catalogue des lichens et champignons lichénicoles de France métropolitaine. Association française de lichénologie, Fontainebleau

Schoch CL, Seifert KA, Huhndorf S, Robert V, Spouge JL, Levesque CA, Chen W and the Fungal Barcoding Consortium (2012) Nuclear ribosomal internal transcribed spacer (ITS) region as a universal DNA barcode marker for Fungi. Proc Natl Acad Sci USA 109:6241-6246

Schwendener S (1868) Untersuchungen über den Flechtenthallus. Beitr Wiss Bot 6:195-207

Seaward MRD (ed)(1998) Lichen Atlas of the British Isles. Fascicle 3. The Foliose Physciaceae (Anaptychia, Heterodermia, Hyperphyscia, Phaeophyscia, Physcia, Physconia, Tornabea), Arctomia, Lobaria, Massalongia, Pseudocyphellaria, Psoroma, Solorina, Sticta, Teloschistes. British Lichen Society, London

Sérusiaux E, Villarreal AJC, Wheeler T, Goffinet B (2011) Recent origin, active speciation and dispersal for the lichen genus Nephroma (Peltigerales) in Macaronesia. J Biogeogr 38:1138-1151

Smith CW, Aptroot A, Coppins BJ, Fletcher A, Gilbert OL, James PW, Wolseley PA (eds) (2009) The Lichens of Great Britain and Ireland. British Lichen Society, London

Soukup J (1965) Lista de liquenes del Peru. Biota [Lima] 6:28-45
Stamatakis A (2006) RAxML-VI-HPC: maximum likelihood-based phylogenetic analyses with thousands of taxa and mixed models. Bioinformatics 22:2688-2690

Stamatakis A, Hoover P, Rougemont J (2008) A rapid bootstrap algorithm for the RAxML web servers. Syst Bio 57:758-771

Stiller JW, Hall BD (1997) The origin of red algae: implications for plastid evolution. Proc Natl Acad Sci U S A 94:4520-4525

Suárez A, Lücking R (2013) Sticta viviana (lichenized Ascomycota: Peltigerales: Lobariaceae), a new species from Colombian paramos. Lichenologist 45:153-157

Swinscow TDV, Krog H (1988) Macrolichens of East Africa. British Museum (Natural History), London

Swofford DL (2002) PAUP* Phylogenetic Analyses Using Parsimony. Version 4.0. Sinauer Associates, Sunderland

Takahashi K, Wang LS, Tsubota H, Deguchi H (2006) Photosymbiodemes Sticta wrightii and Dendriscocaulon sp. (lichenized Ascomycota) from Yunnan, China. J Hattori Bot Lab 100:783-796

Templeton A, Crandall K, Sing C (1992) A cladistic analysis of phenotypic associations with haplotypes inferred from restriction endonuclease mapping and DNA sequence data. III. Cladogram estimation. Genetics 132:619-633

Thomas MA, Ryan DJ, Farnden KJF, Galloway DJ (2002) Observations on phylogenetic relationships within Lobariaceae Chevall. (Lecanorales, Ascomycota) in New Zealand, based on ITS-5.8s molecular sequence data. Bibliotheca Lichenologica 82:123-138

Tønsberg T, Goward T (2001) Sticta oroborealis sp. nov., and other Pacific North American lichens forming dendriscocauloid cyanotypes. Bryologist 104:12-23

Tripp EA, Lendemer JC (2014) Sleepless nights: when you can't find anything to use but molecules to describe new taxa. Taxon 63 : 969-971

Upreti DK, Divakar PK (2010) A new species in the lichen genus Sticta (Schreb.) Ach. (Lobariaceae) from the Indian subcontinent. Nova Hedwigia 90:251-255

Vilgalys R, Hester M (1990) Rapid genetic identification and mapping of enzymatically amplified ribosomal DNA from several Cryptococcus species. J Bacteriol 172:4238-4246

Wheeler DL, Barrett T, Benson DA, Bryant SH, Canese K et al (2007) Database resources of the national center for biotechnology information. Nucleic Acids Res 35:D5-D12

White TJ, Bruns T, Lee S, Taylor J (1990) Amplification and direct sequencing of fungal ribosomal RNA genes for phylogenetics. PCR Protocols: Guide Meth Appl 18:315-322

Wirth V (1995) Die Flechten Baden-Württembergs, Teil 1 \& 2. Eugen Ulmer GmbH \& Co., Stuttgart

Wirth V, Hauck M, Schultz M (2013) Die Flechten Deutschlands. Eugen Ulmer KG, Stuttgart

Zahlbruckner A, Hauman L (1936) Les lichens des hautes altitudes au Ruwenzori. Mémoires Inst Royal Colonial Belge Section Sci Naturelles Méd 5:1-31

Zoller S, Scheidegger C, Sperisen C (1999) PCR primers for the amplification of mitochondrial small subunit ribosomal DNA of lichenforming ascomycetes. Lichenologist 31:511-516 